\title{
Capítulo
}

2

\section{Modelagem da Estratégia e Alinhamento de Recursos Humanos Baseado em Competências}

\author{
Henrique Prado de Sá Sousa, Eduardo Kinder Almentero
}

\begin{abstract}
The objective of this short course is to present an organizational modeling language that addresses the topic of competency-based human resources strategy and alignment. This theme brings a large volume of concepts, then the short course is practiceoriented, dividing the presentation of the content into well-defined parts, which can also be used separately. The composition of the developed models will foster strategic analysis based on human resources competencies. The models will be developed from a mini-world designed to facilitate learning. In the end, students will have the experience of modeling processes, organizational objectives, context situations, and human resources skills, in a language that integrates these models, allowing analyzes that help in strategic decisions.
\end{abstract}

\section{Resumo}

O objetivo deste minicurso é apresentar uma linguagem de modelagem organizacional que aborda o tema de estratégia e alinhamento de recursos humanos baseado em competências. Como o tema traz um volume grande de conceitos, o minicurso é orientado à prática, dividindo a apresentação do conteúdo em partes bem definidas, as quais podem também ser utilizadas em separado. A composição dos modelos desenvolvidos irá fomentar a análise estratégica baseada em competências de recursos humanos. Os modelos serão desenvolvidos a partir de um minimundo projetado para facilitar o aprendizado. Ao final, os alunos terão a experiencia de modelar processos, objetivos organizacionais, situações de contexto e competências de recursos humanos em uma linguagem que integra esses modelos permitindo análises que auxiliam em decisões estratégicas.

\subsection{Introdução}

\subsubsection{Estratégia Organizacional}

As organizações experimentaram recentemente o peso de mudanças drásticas ocasionadas por eventos pouco considerados em sua rotina de gestão. A pandemia da 
Covid-19 criou circunstâncias diversificadas, resultando em provações difíceis para inúmeras organizações, mas também criando cenários favoráveis para o crescimento e/ou estabelecimento de determinados tipos de negócios.

Apesar de uma pandemia ser um evento com baixa probabilidade de ocorrer no tempo, não é possível determinar com exatidão as condições do porvir. A experiência enfrentada de forma global demonstra que, na prática, os efeitos advindos das relações sociais no mundo são capazes de interferir sobremaneira em variáveis de interesse de muitas organizações, uma vez que afetam, por exemplo, as economias, os custos, consumo, as cadeias de produção, e até o capital humano, por impactos em sua forma costumeira de vida.

As mudanças contínuas no contexto das organizações são um fato. Elas demandam determinado grau de adaptação para que as organizações permaneçam em condições de cumprir os seus propósitos.

Uma forma de minimizar o impacto de mudanças se baseia no estudo de potenciais cenários futuros, antecipando-se no preparo e planejamento de ações para que, no caso de enfrentamento real destes cenários, a organização esteja preparada para se adequar às novas condições, as quais podem demandar alterações impactantes em tempo diminuto.

As estratégias de uma organização são definidas a partir de seus objetivos, que expressam sobremaneira os estados futuros que a organização almeja. Todas as ações que são projetadas na definição do percurso a ser trilhado visando sair de um estado atual para o estado futuro de desejo são, normalmente, pensadas em pormenores para aumentar as possibilidades de mitigar impactos negativos que porventura surjam na caminhada.

Para apoiar esse processo de construção de estratégias, diversas ferramentas foram propostas, por exemplo Balanced ScoreCard (BSC) [Kaplan e Norton, 1992], Análise SWOT [Pickton e Wright, 1998], 5 forças de Porter [Porter, 1980], VRIO Framework [Barney, 1992] e Strategyzer canvas [Strategyzer, 2015].

Neste minicurso apresentamos uma linguagem de modelagem organizacional que permite registrar informações sobre as variáveis que compõem o contexto organizacional, e vinculá-las às estratégias. As estratégias, por sua vez, podem ser descritas em termos de seus objetivos, processos e tarefas ${ }^{1}$, permitindo registrar detalhes sobre a sua implementação.

\subsubsection{Alinhamento Organizacional}

O trabalho minucioso de projeção de estratégias é apenas o início de um ciclo de gestão na organização. Uma vez definidas as estratégias, inicia-se o grande desafio de implementá-las. Este desafio é caracterizado pela tarefa de coordenar a estrutura organizacional para que atenda da melhor forma possível aos interesses da organização.

Como uma organização é composta por muitas áreas com atuações distintas (apesar de complementares no contexto organizacional), existe um vasto campo literário e científico para cada uma dessas áreas. Isso inclui técnicas e métodos específicos para o alinhamento organizacional.

\footnotetext{
${ }^{1}$ Tarefa também é comumente referenciada como Atividade. Neste trabalho adotamos o termo Tarefa.
} 
Também abordamos o conceito de competências, bastante utilizado na gestão de Recursos Humanos (RH). Através da modelagem de competências são registrados os requisitos humanos para a realização de tarefas na organização. A avaliação do alinhamento de RH consiste na medição das capacidades reais de um indivíduo em corresponder aos requisitos das competências necessárias para lidar com as responsabilidades de determinado papel organizacional.

Utilizando a linguagem GPI-HR [Sousa e Leite, 2017a], é possível modelar e relacionar os requisitos de competências ao modelo que descreve estratégias e, através de relacionamentos, manter o rastro de potenciais impactos que eventuais (des) alinhamentos possam criar. Essencialmente, a linguagem auxilia na análise estratégica organizacional e de $\mathrm{RH}$ ao apresentar nos modelos marcadores que simplificam o entendimento do cenário existente, demarcado principalmente por informações sobre o "alinhamento de RH" e "Situação de contexto".

Adotaremos uma abordagem que empregará exemplos simples para facilitar o entendimento da linguagem GPI-HR. Através de uma abordagem "botton-up", apresentaremos todos os modelos envolvidos. Na demonstração de exemplos, apresentamos "minimundos" seguidos de sua respectiva modelagem.

\subsubsection{Organização do Capítulo}

O minicurso foi organizado da seguinte forma: primeiramente apresentamos brevemente informações sobre a ferramenta de modelagem GPI-HR. Posteriormente, apresentamos o conceito de competências e seus recursos de modelagem. Em seguida abordamos o tema de modelagem de processos, modelagem de estratégia e situações de contexto. Adicionalmente, foram debatidas as formas de uso e propagação de marcadores que são utilizados para auxiliar a análise do alinhamento. Por fim, o uso dos modelos em análises de alinhamento será exemplificado.

Cada tema apresentado é seguido de um exemplo. As experiências e análises dos autores também são apresentadas.

\subsection{A Linguagem de Modelagem GPI-HR}

Este minicurso apresenta um conjunto de conceitos envolvidos na modelagem da estratégia, competências e alinhamento de RHs, os quais são aplicados na ferramenta GPI-HR ${ }^{1}$.

Essa ferramenta é continuamente atualizada para abordar conceitos envolvidos na modelagem organizacional, mais especificamente, orientada ao alinhamento organizacional. Isso representa obter conhecimento de diversas áreas e incorporar à linguagem de modelagem de forma a representar conceitos importantes e seus impactos através dos modelos.

A linguagem GPI (Goal, Process, Indicators) foi projetada para permitir maior grau de rastreabilidade entre elementos da camada de processos e elementos da camada de objetivos [Sousa e Leite, 2014], [Sousa e Leite, 2015], visando ampliar a possibilidade de se analisar o alinhamento entre essas camadas. Posteriormente, a linguagem evoluiu para o GPI-HR (Goal, Process, Indicators - Human Resources) para melhor abordar os conceitos de estratégia, competência, e alinhamento de RHs [Sousa e Leite, 2017a], [Sousa e Leite, 2017b].

${ }^{1}$ gpi.uniriotec.br 
A linguagem GPI-HR utiliza "padrões de modelagem” [Sousa e Leite, 2017b] que definem um formato de modelagem para um conceito bem definido na linguagem. Isso permite oferecer modelos para a modelagem de conceitos específicos, bem como a possibilidade de anexá-los como módulos no modelo principal, agregando informações de alinhamento.

Como a linguagem GPI-HR visa, em especial, auxiliar na análise do alinhamento organizacional e do alinhamento da perspectiva de $\mathrm{RH}$, os marcadores se adaptam a expressar estados qualitativos resultantes, eliminando, à primeira vista, a complexidade dos cálculos de indicadores comuns.

Os marcadores são baseados nas cores vermelho, amarelo e verde, que possuem semânticas universais, inclusive usado em sinais de trânsito em todo o mundo. $O$ vermelho representa o PARE, o amarelo representa ATENÇÃO, e o verde representa SIGA.

Se tratando de marcadores que representam indicadores, a analogia que fazemos é que o vermelho representa nível abaixo do esperado, o amarelo em algum nível que represente risco, próximo ao abaixo do esperado (ou próximo do esperado, conforme se desejar definir com ou uso dos marcadores), o verde representa dentro do nível esperado, e adicionalmente incluímos o azul, representando o que houver acima do esperado. A Figura 2.1 ilustra os marcadores e suas cores.

\section{OOO}

\section{Figura 2.1. Cores dos marcadores no GPI-HR.}

As semânticas das cores são adaptadas para representar de forma adequada o elemento em que a marcação estiver relacionada. Entretanto, espera-se que o entendimento rápido da leitura dos modelos por usuários siga por uma semântica genérica, conforme apresenta a Tabela 2.1:

Tabela 2.1. Semânticas abstratas dos marcadores do GPI-HR.

\begin{tabular}{|c|l|}
\hline Marca & Possíveis semânticas \\
\hline$\bigcirc$ & Acima do esperado, melhor caso, contribuição superior, alinhamento superior. \\
\hline$\bigcirc$ & \begin{tabular}{l} 
Satisfatório, esperado, existente, verdadeiro, contribuição positiva, alinhado. \\
\hline$\bigcirc$
\end{tabular} \\
\hline$\bigcirc$ & $\begin{array}{l}\text { Abaixo do esperado, pouco insatisfatório, em atenção, em risco, contribuição negativa, } \\
\text { pouco desalinhado. } \\
\text { Muito insatisfatório, insuficiente, inexistente, falso, sem contribuição, muito } \\
\text { desalinhado. }\end{array}$ \\
\hline
\end{tabular}

Os marcadores são inseridos no topo esquerdo dos elementos mensurados (Figura 2.2).
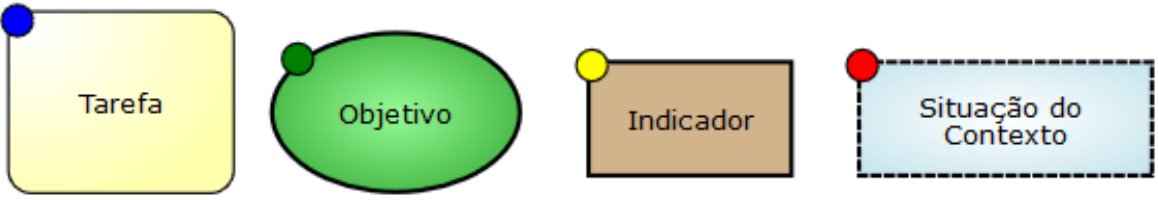

Figura 2.2. Exemplo de marcadores em elementos da linguagem.

No decorrer do minicurso abordaremos os conceitos apresentados são seguidos de exemplo de uso na linguagem GPI-HR. O uso dos marcadores nos diferentes modelos da linguagem é explicado à medida em que esses modelos são apresentados. 


\subsubsection{Competência}

Competência é geralmente ${ }^{1}$ definida em termos do nível de "Conhecimento (Knowledge), Habilidades (Skills) e Aptidões/Talentos (Abilities)" que possibilita a uma pessoa o potencial para efetivamente realizar uma tarefa [Curtis et al., 2009], [Stevens, 1994]. A tríade Knowledge, Skill e Ability é também conhecida como KSA Framework [Tripathi e Agrawal, 2014], em português, referenciado como CHA.

Existem diversas variantes propostas por outros autores [Trichet e Leclère, 2003]. Por exemplo, [Carbone et al., 2005] faz referência a Atitudes (Attitudes) no lugar de Aptidões (Abilities). Outros autores podem substituir por Comportamento (behaviour), Habilidade física (physical ability) ou outras variações similares [Klink e Boon, 2002], [Trichet e Leclère, 2003], [Draganidis e Mentzas, 2006]. Independente das variações, trata-se de uma ferramenta bastante difundida na gestão baseada em competências [Draganidis e Mentzas, 2006].

No entanto, essa definição em termos de CHA oferece apenas uma expectativa de bons resultados, uma vez que não é uma regra para o desempenho. O conceito de competência definido por [Fleury e Fleury, 2001], [Dutra, 2007] preenche essa lacuna porque está necessariamente relacionado a um resultado mensurável.

Portanto, espera-se que um indivíduo tenha uma competência determinada somente se tiver os conhecimentos, habilidades e aptidões necessárias e aplicá-las sob determinado desempenho esperado, atendendo as medidas de competências [Fleury e Fleury, 2001], [Carbone et al., 2005], [Dutra, 2007], [Curtis et al., 2009].

Esse conceito se aproxima da definição de [Carbone et al., 2005]: "combinações sinérgicas de conhecimentos, habilidades e atitudes, expressas pelo desempenho profissional dentro de determinado contexto organizacional, que agregam valor a pessoas e organizações"; e da definição do P-CMM, a qual é referenciada como "Competência da força de trabalho" e que "representa uma única integração de conhecimento (knowledge), habilidades (skills) e aptidões de processos (process abilities) adquiridas através da educação especializada e da experiência de trabalho".

A proposta utilizada neste minicurso considera o conceito de competência em termos de "Conhecimentos, Habilidades e Aptidões", sendo:

- Conhecimento: é a informação e o entendimento que um indivíduo deve ter para realizar uma tarefa com sucesso.

- Habilidades: são as habilidades técnicas que um indivíduo adquire através do aprendizado, geralmente na aplicação do conhecimento.

- Aptidões: são habilidades/comportamentos individuais, normalmente inatas, porém também podem ser adquiridas.

O conceito de Competência é abordado na literatura de RH considerando diferentes graus de abstração e profundidade (detalhamento). É avaliado a partir de uma perspectiva operacional quando relacionado a pessoas e tarefas de processo [Curtis $e t$ al., 2009]; e estratégica, quando vista como um diferencial organizacional [Prahalad e Hamel, 1990]. Porém, também se relaciona com as teorias do aprendizado, tanto no contexto da Psicologia quando faz referência ao ser humano, quanto da Administração, quando faz referência ao conhecimento e aprendizado organizacional.

${ }^{1} \mathrm{O}$ conceito de competência possui variações em sua definição na literatura motivada por diferentes visões, autores e contexto histórico [Brandão e Guimarães, 2001]. 
Sob a perspectiva do conhecimento geral, a Competência é comumente relacionada ao conhecimento individual, adquirido através da academia, entretanto, sob a perspectiva estratégica de $\mathrm{RH}$, o conceito de Competência é revisto de forma a atender as demandas das organizações complexas que se encontram em constante evolução e adaptação [Fleury e Fleury, 2011].

$\mathrm{Na}$ camada operacional, o conceito de Competência se relaciona aos atores organizacionais em ação; do ponto de vista das tarefas, as Competências são listadas em termos de requisitos para que ela seja realizada de forma correta e satisfatória. Nesse sentido, Competência se encontra relacionada à performance que, por conseguinte, se correlaciona à mensuração. [Dutra, 2007], [Vignotto, 2015], [Fleury e Fleury, 2000] destacam a relação da Competência com o resultado, o que possivelmente justifique, através da avaliação do retorno de uma competência, a ligação ao conceito de estratégia organizacional.

A relação da Competência com o recurso humano e as tarefas as quais são de sua responsabilidade é a visão mais reduzida na observação da interação destes elementos, dentro do contexto organizacional. Novas competências são alcançadas quando as pessoas e suas competências individuais são postas em ação em grupos multidisciplinares. Ou seja, uma equipe de indivíduos é capaz de gerar novas competências através do esforço conjunto de suas competências individuais, principalmente em ambientes multidisciplinares.

Portanto, as competências possuem uma condição especial de se estabelecerem a partir da colaboração de duas ou mais pessoas, entregando suas competências individuais. Por exemplo, na construção de um prédio, vários profissionais atuam juntos, integrando diversas competências que, ao final, alcança a competência "Construção de prédio". Entretanto, nenhuma das pessoas possui essa competência quando avaliadas em termo de indivíduo. O mesmo efeito se estabelece na definição das "competências organizacionais".

O termo "entrega de competência" vem da tradução do termo "competence delivery", que é um termo comumente utilizado. Utilizaremos este termo aqui. Esse termo reforça o entendimento da competência como um produto ou serviço bem definido que é entregue a um interessado.

\subsubsection{Relações Entre Competências Humanas e as Competências da Organização}

A definição das competências organizacionais pode ser direcionada a partir da análise da missão, objetivos estratégicos e valores da organização. As competências individuais e suas configurações em grupos de trabalho podem ser mapeadas a partir das competências organizacionais [Maia, 2011]. No entanto, o inverso também é verdadeiro, quando as competências organizacionais são projetadas a partir das competências humanas existentes.

Pelo seu nível de abstração e complexidade, as competências organizacionais podem expressar os potenciais produtivos da organização, os quais estabelecem suas vantagens competitivas e são de relevância fundamental para alcance dos objetivos estratégicos [Fleury e Fleury, 2001], [Prahalad e Hamel, 1990].

Quando observadas do ponto de vista estratégico, nem todas as competências organizacionais são necessariamente implementadas pela organização. A seleção das competências chave serão balizadas pela estratégia da organização. O conjunto de competências com vínculo estratégico é denominado Competências Essenciais. 
Segundo [Prahalad e Hamel, 1990], as competências essenciais (core competences) devem ter as seguintes características: oferecer reais benefícios aos consumidores, serem difíceis de imitar e possibilitar acesso a diferentes mercados. São essas competências que diferenciam a organização e que lhe garantem uma vantagem competitiva sustentável perante as demais organizações [Fleury e Fleury, 2004].

As competências essenciais não devem ser confundidas com as competências individuais ou de grupo (ou da força de trabalho, conforme [Curtis et al., 2009] uma vez que se encontram em diferentes níveis de abstração. As competências individuais/grupo estão presentes em um nível inferior (ou mais operacional), relacionadas com o perfil de conhecimento, habilidades e aptidões que são demandadas para se realizar as tarefas organizacionais, funcionando como arcabouço estratégico das competências essenciais da organização [Curtis et al., 2009].

Fleury e Fleury (2004) afirmam que as Competências Organizacionais e Essenciais são como elementos constituídos a partir da combinação de recursos e de múltiplas competências individuais, de tal forma que o resultado total é maior do que a soma das competências individuais.

$\mathrm{Na}$ prática organizacional, observamos que a construção das competências organizacionais é decorrente dos processos de colaboração entre competências específicas. Dentro da estrutura organizacional, alguns componentes podem ser provedores de competência. O mais comum são as competências provenientes dos RHs, entretanto os aparatos tecnológicos como softwares e máquinas são introduzidos nas organizações com o objetivo de apoiar na entrega de competências ou ainda, se responsabilizar integralmente por elas.

A tecnologia comumente absorve as competências humanas, mas, não raro, as potencializa de forma substancial, por exemplo, nas grandes máquinas empregadas em processo agrícolas, ou em computadores que analisam grandes volumes de dados.

Independente dos diferentes níveis de qualidade de competência, é através dos processos colaborativos que as competências interagem, gerando competências de valor altamente agregado, não se confundindo com a mera soma de competências (Figura 2.3).

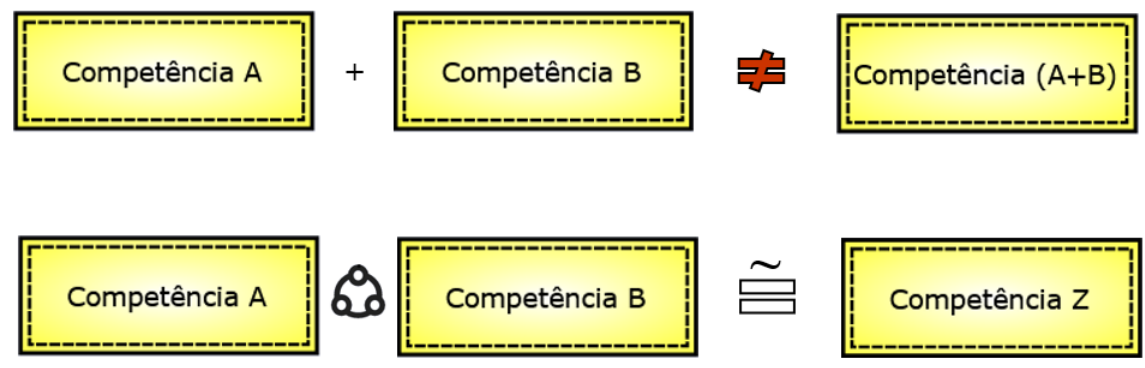

Figura 2.3. Interação colaborativa entre competências.

As competências organizacionais são geralmente apresentadas no portifólio organizacional, caracterizados pelos produtos e serviços que ela oferece aos seus clientes. São as competências de maior valor agregado na organização, e são alcançadas através da contribuição de diversas competências que se agregam através dos processos de produção da organização, os quais demandam de seus responsáveis sua colaboração no processo de construção destas competências finais (Figura 2.4). 


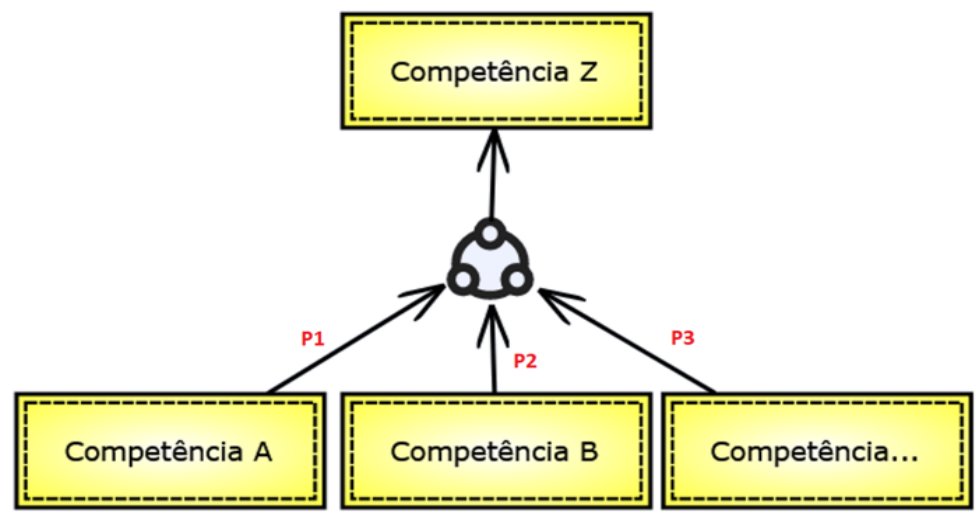

Figura 2.4. Diferentes contribuições de competências no processo interativo.

Cabe destacar que essas competências entregues pela organização podem servir de insumo para outras organizações agregarem ainda mais valor, gerando entregáveis mais agregados. Um exemplo é a construção de um veículo o qual é composto por partes provenientes de diversas empresas, contendo produtos bem delineados tecnologicamente por organizações especializadas.

Uma estrutura organizacional não reproduz toda a sua capacidade nos produtos e serviços presentes no portifólio, assim como uma pessoa, ocupando determinado papel, não oferece toda a sua capacidade na implementação de suas reponsabilidades.

O conhecimento dos potenciais de uma estrutura organizacional é muito importante no contexto estratégico porque apresenta os seus limites, auxiliando nas decisões. Esta é uma das motivações da implementação da gestão por competências. Primeiro porque mapeia os requisitos de competências (mapa de competências) para a implementação de estratégias. Segundo porque mapeia a capacidade de entrega de competências da estrutura organizacional. Sabe-se que somente se gerencia algo que se conhece bem. A gestão de competências torna-se um recurso que apoia a aquisição deste conhecimento, bem como o seu acompanhamento.

Com este conhecimento, decisões estratégicas podem ser mais efetivas, pois é possível pontuar com maior precisão quais caminhos estratégicos a organização é capaz de atender. Ademais, caso se identifique a necessidade de competências que a organização não possui, é possível analisar estratégias para a aquisição de novas competências. Adquirir competências pode, por exemplo, se resumir a uma terceirização, ou ainda, no treinamento de pessoas ou aquisição de insumos tecnológicos.

Para se avaliar as competências de RHs é necessário primeiro mapear as competências requeridas. Essas competências estão relacionadas às responsabilidades de um ator organizacional. Mais detalhadamente, nos processos os quais aquele determinado ator deve implementar.

As competências são requisitos à estrutura da organização que deseja alcançar determinados objetivos. É através do emprego destas competências que todo o processo de realização pode ser implementado dentro dos quesitos de qualidade necessários. Tudo o que se faz demanda alguma competência. É possível observar, sob esta ótica, que desde o nascimento de um indivíduo, competências são desenvolvidas, a começar pelas primordiais que o habilitarão a realizar tarefas mais complexas. Portanto, competências podem ser observadas como requisitos de outras competências de maior valor agregado. 
As competências podem ser vinculadas como requisitos a objetivos, processo e tarefas, os quais são elementos fundamentais na modelagem organizacional, e estão relacionados sob uma hierarquia de abstração (Figura 2.5). Um processo é composto por tarefas e é projetado para alcançar determinados objetivos. É possível identificar requisitos de competência para tarefas simples, e de forma agregada, observa-se os requisitos de processos e de seus objetivos.

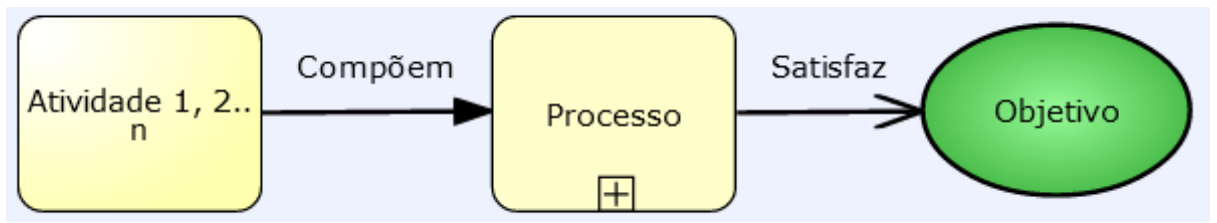

Figura 2.5. Relação entre tarefa x processo x objetivo.

Sob a visão da gestão de competências, essa relação se altera para incorporar o conceito de competências, com sua dinâmica e viés estratégico. A Visão Baseada em Recursos ou Resource Based View (RBV) [Penrose, 1959] apresenta uma visão mais maleável e adaptável quando considera que os recursos devem estar aptos a se reorganizarem para oferecer as mesmas competências, ainda que sob o desafio de cenários diversificados. Isso torna a competência um elemento fixo capaz de satisfazer os objetivos para os quais ele foi definido, mas variável nos processos de implementação (Figura 2.6), que se adaptam estrategicamente às mudanças.

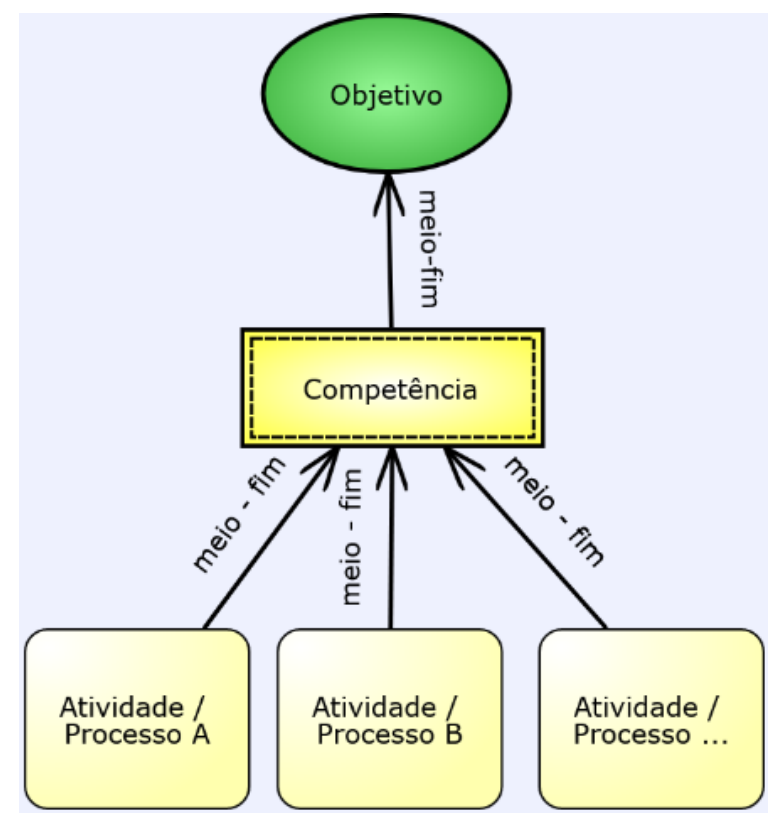

Figura 2.6. Representação da variabilidade de operacionalizações para uma competência através dos relacionamentos de meios-fim.

Essa visão se alinha a necessidade de se planejar ações estratégicas capazes de lidar com as mudanças presentes no mundo, bem como pontua a responsabilidade de se entregar as competências à estrutura da organização. Essa noção é reforçada pela relação de competências vinculadas aos objetivos estratégicos (core competences), também definido como o portfólio estratégico de competências da organização [Prahalad e Hamel, 1990].

Também baseado na teoria da RBV [Stirna et al., 2012], [Loucopoulos et al., 2015], o conceito de Capacidade é referenciado por diversas propostas sob as mesmas características identificadas para competência. Inclusive, há autores que adotam o termo “Capacidades principais" (Core capabilities) [Azevedo et al., 2015], [Grant, 1996]. 


\subsubsection{Padrão de Perfil de Competências}

O perfil de competências segue um padrão de modelagem na linguagem GPI-HR. É a composição do perfil de Conhecimento, Habilidades e Aptidões, conforme apresentado na sessão 2.3.1.

Cada elemento CHA modelado pode se relacionar ao respectivo perfil através de dois possíveis relacionamentos. O primeiro é o relacionamento de "contribuição positiva" (Help), o que significa que aquele elemento ajuda a melhorar o perfil de conhecimento. Entretanto, os elementos que se relacionam através da "contribuição positiva" não são obrigatórios ao perfil. São elementos desejáveis e que, se presentes, fomentam um perfil melhor.

A segunda relação é de "E" (AND). Os elementos relacionados pelo "E" são obrigatórios. Cada elementos CHA também podem ser de dois tipos, mensurado ou não mensurado. Os elementos mensurados estão vinculados a indicadores de desempenho que irão expressar o seu grau através de algum mecanismo de medição. Os elementos que não estão vinculados a indicadores podem ser medidos através de avaliações informais.

A figura 2.7 apresenta o padrão de modelagem do Perfil de Competência.

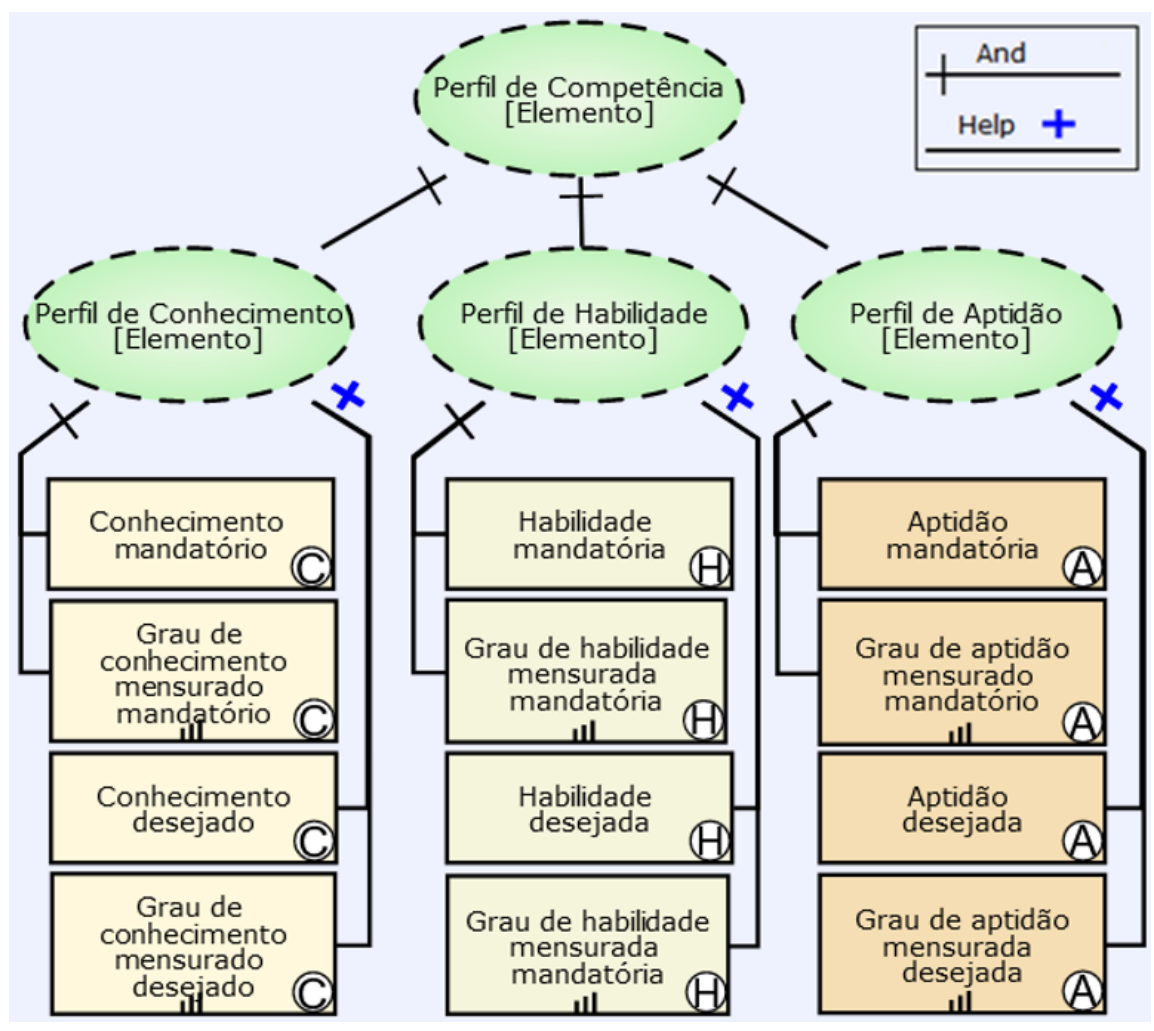

Figura 2.7. Padrão de modelagem para Perfil de Competência.

Este perfil pode ser usado para modelar os requisitos de competência para determinado elemento ou conjunto de elementos, os quais podem ser um papel organizacional, uma competência, um processo, uma tarefa ou um objetivo. Quando o perfil de competência modela requisitos, ele é chamado de Perfil Requerido [Sousa e Leite, 2017a]. 
O Perfil Requerido pode ser medido, sendo preenchidos por valores nos elementos CHAs, se transformando em um Perfil Real ou Perfil Mensurado. Este perfil pode representar valores de um recurso humano ou grupo de recursos humanos. Entendemos que este perfil também pode ser aplicado à tecnologia, no entanto, não observamos estudos ou relatos deste tipo de aplicação.

A comparação de um Perfil Requerido e um Perfil Real possibilita a avaliação do alinhamento de RH. A partir desta comparação são evidenciados os possíveis desvios de um RH em relação aos quesitos da organização. Portanto, para que seja possível avaliar o alinhamento de RH é necessário primeiramente que a organização entenda bem quais são as suas necessidades nos diversos níveis.

\subsubsection{Exemplo - Modelando o Perfil de Competências Requerido}

Para exemplificar a modelagem de um perfil de competências, foi utilizado o tema "Fazer bolo" a fim de motivar o pensamento sobre os requisitos de CHA envolvidos neste processo. A Figura 2.8 apresenta o resultado de um perfil de competências requerido elaborado sem formalidades, apenas para compor um exemplo.

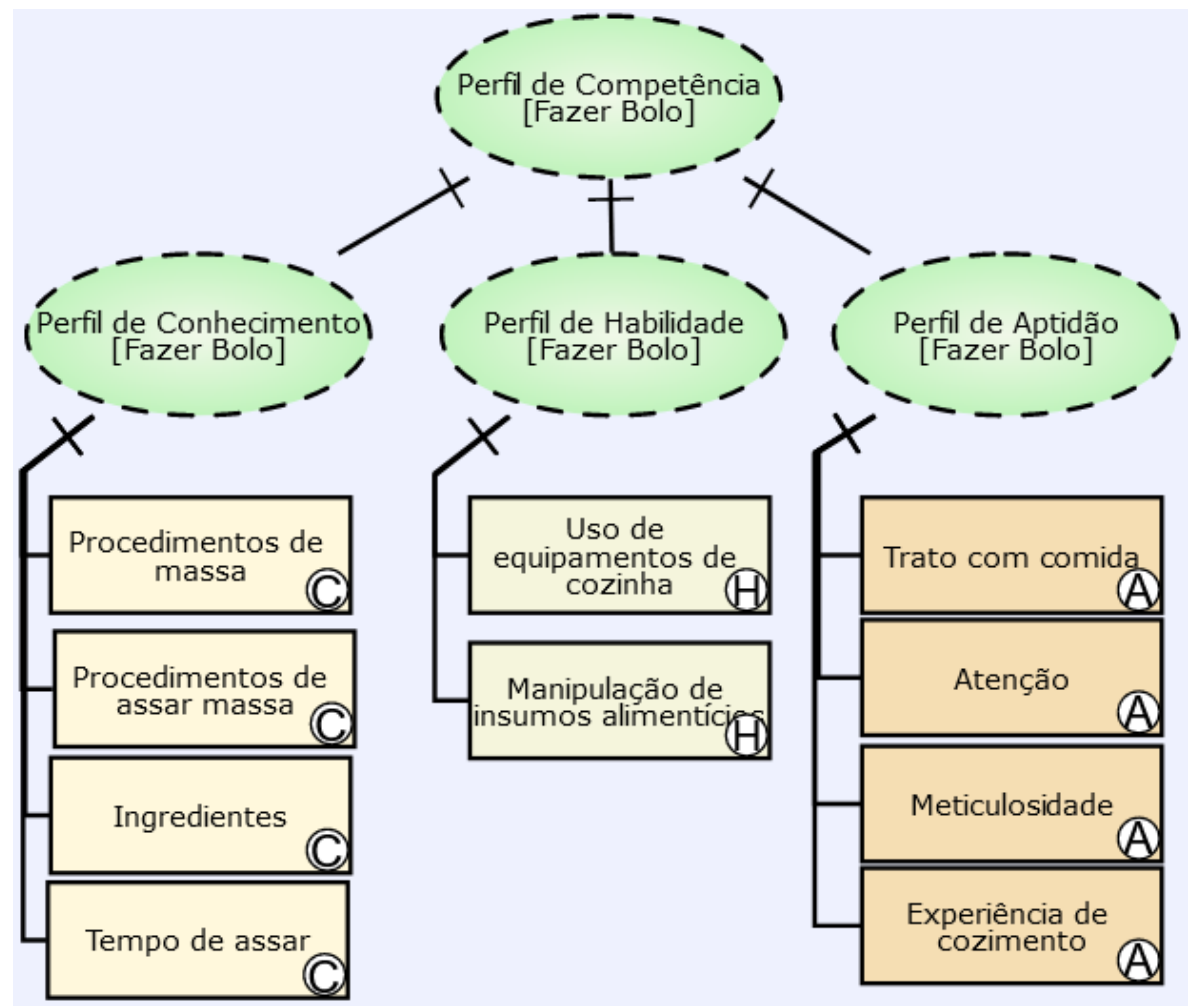

Figura 2.8. Exemplo de perfil de competência requerido para o processo "Fazer bolo".

Todos os elementos definidos foram relacionados como obrigatórios. Quatro conhecimentos foram mapeados: Procedimentos de massa, representando 0 conhecimento de como fazer a massa do bolo; Procedimentos de assar, massa representando o conhecimento necessário para colocar a massa para assar corretamente; Ingredientes, representando o conhecimento de todos os elementos que devem compor; e Tempo de assar, representando o conhecimento sobre o tempo adequado de assar determinado tipos de massa de bolo.

No perfil de habilidade foram identificados duas habilidades: uso de equipamentos de cozinha, representando as habilidades necessárias para lidar com a manipulação e operação segura e correta dos equipamentos necessários no processo de 
"Fazer bolo"; e Manipulação de insumos alimentícios, representando as habilidades necessárias para operar com alimento, o que permitirá fazer composições adequadas, organização, e limpeza, sem estragar os alimentos ou criar resultados desfavoráveis durante a manipulação dos insumos.

No perfil de aptidões, foram identificados quatro elementos: trato com comida, que representa a aptidão de atuar de forma respeitosa, asseada e responsável com o alimento; Atenção, representando a necessidade de se observar os procedimentos e seus riscos, bem como o tempo de preparo para que não cause acidentes ou estrague o alimento; Meticulosidade, representando a capacidade de observar os pormenores durante o trabalho, e seguir os procedimentos à risca para obter resultados de maior qualidade; Experiência de cozimento, representando a necessidade de já ter experiência nos processos de cozimento, o que permitirá ao indivíduo o melhor trato em circunstâncias inesperadas, contorno de problemas e decisões mais adequadas ao sucesso do trabalho.

Todos esses elementos juntos compõem os requisitos humanos mapeados para que um indivíduo consiga realizar de forma adequada o processo de "Fazer bolo". Observamos que as aptidões do exemplo são qualidades humanas que auxiliam na qualidade do trabalho, sem as quais, torna-se menor a probabilidade de sucesso. Todos os elementos CHA são obrigatórios, portanto, na ausência de qualquer um deles, ou em alguma avaliação insuficiente, observa-se o risco em algum grau, de não se alcançar a satisfação dos objetivos na implementação do processo, uma vez que se observa a possibilidade de problemas de execução devido a insuficiência de um ou mais CHAs necessários.

\subsubsection{Exemplo - Modelando o Perfil de Competências Real}

O Perfil Real é o Perfil Requerido quando instanciado para um RH. Nessa instância, todos os elementos CHA são medidos e, ao final, propaga-se os valores para os elementos superiores até exibir o marcador no Perfil de Competências, o qual também representa o marcador de Alinhamento de RH.

\section{Marcadores no Perfil Real / Mensurado}

Nos Perfis de CHA são registrados elementos mensuráveis e não mensuráveis.

Os elementos mensuráveis recebem a marcação dos seus indicadores de desempenho.

Os indicadores de desempenho são usados para medir elementos diversos de forma quantitativa ou qualitativa. Os marcadores expressam o grau de satisfação dos indicadores de desempenho. A classificação semântica dos marcadores dos indicadores é dividida em quatro intervalos, conforme apresenta a Tabela 2.2:

Tabela 2.2. Semântica dos marcadores para Indicadores de desempenho.

\begin{tabular}{|c|l|}
\hline Marca & Semântica \\
\hline$\bigcirc$ & O indicador está acima do intervalo esperado. \\
\hline$\bigcirc$ & O indicador está dentro do intervalo esperado. \\
\hline$\bigcirc$ & $\begin{array}{l}\text { O indicador está em uma zona próximo do menor valor esperado e/ou pouco abaixo do } \\
\text { intervalo esperado, porém ainda aceito. Possibilidade de risco controlado. }\end{array}$ \\
\hline$\bigcirc$ & O indicador está abaixo do pior intervalo aceito. \\
\hline
\end{tabular}


Os elementos não mensuráveis representam CHAs de valores binários, ou seja, o RH tem ou não tem o atributo. Para estes casos, a marcação só recebe dois valores, conforme mostra a Tabela 2.3.

Tabela 2.3. Marcas para elementos CHA desejados e mandatórios.

\begin{tabular}{|c|l|}
\hline Marca & Semântica \\
\hline$\bigcirc$ & O recurso humano tem o elemento. \\
\hline$\bigcirc$ & O recurso humano não tem o elemento. \\
\hline
\end{tabular}

\section{Marcador de Alinhamento de RH}

O marcador do Perfil de Competência representa um marcador de Alinhamento de RH porque consolida os marcadores dos Perfis CHA. Essa consolidação de marcadores é proveniente de uma propagação baseada no pior caso, ou seja, na presença de elementos com diferentes marcadores dentro do perfil, o marcador que o representará será o de menor grau de avaliação. Isso permite a replicação do impacto negativo de possíveis desalinhamentos, o que facilita a sua identificação através dos modelos.

A Tabela 2.4 apresenta as semânticas possíveis para o marcador de Alinhamento de RH.

Tabela 2.4. Marcadores para Alinhamento de RH.

\begin{tabular}{|c|c|}
\hline Marca & Semântica \\
\hline & $\begin{array}{l}\text { Competente para executar a tarefa com maestria (tem todas as qualidades necessárias em } \\
\text { níveis } \\
\text { RH alinhado, desempenho acima do esperado. }\end{array}$ \\
\hline & $\begin{array}{l}\text { Competente para executar a tarefa (tem todas as qualificações necessárias no nível } \\
\text { satisfatório. Algumas qualidades podem estar em níveis acima do satisfatório). } \\
\text { RH alinhado, desempenho satisfatório. }\end{array}$ \\
\hline & $\begin{array}{l}\text { Parcialmente incompetente para executar a tarefa (tem pelo menos uma qualificação } \\
\text { necessária em nível de atenção. As outras qualidades estão em níveis satisfatórios ou acima). } \\
\text { Desalinhamento de RH, risco assumido. }\end{array}$ \\
\hline & $\begin{array}{l}\text { Incompetente para executar a tarefa (tem pelo menos uma qualificação necessária em nível } \\
\text { abaixo do aceito. As outras qualidades tornam-se indiferentes). } \\
\text { Desalinhamento de RH. }\end{array}$ \\
\hline
\end{tabular}

A Figura 2.9 apresenta um exemplo de Perfil Real, instanciado do Perfil Requerido presente na Figura 2.8, para a Sra. Mafalda. 


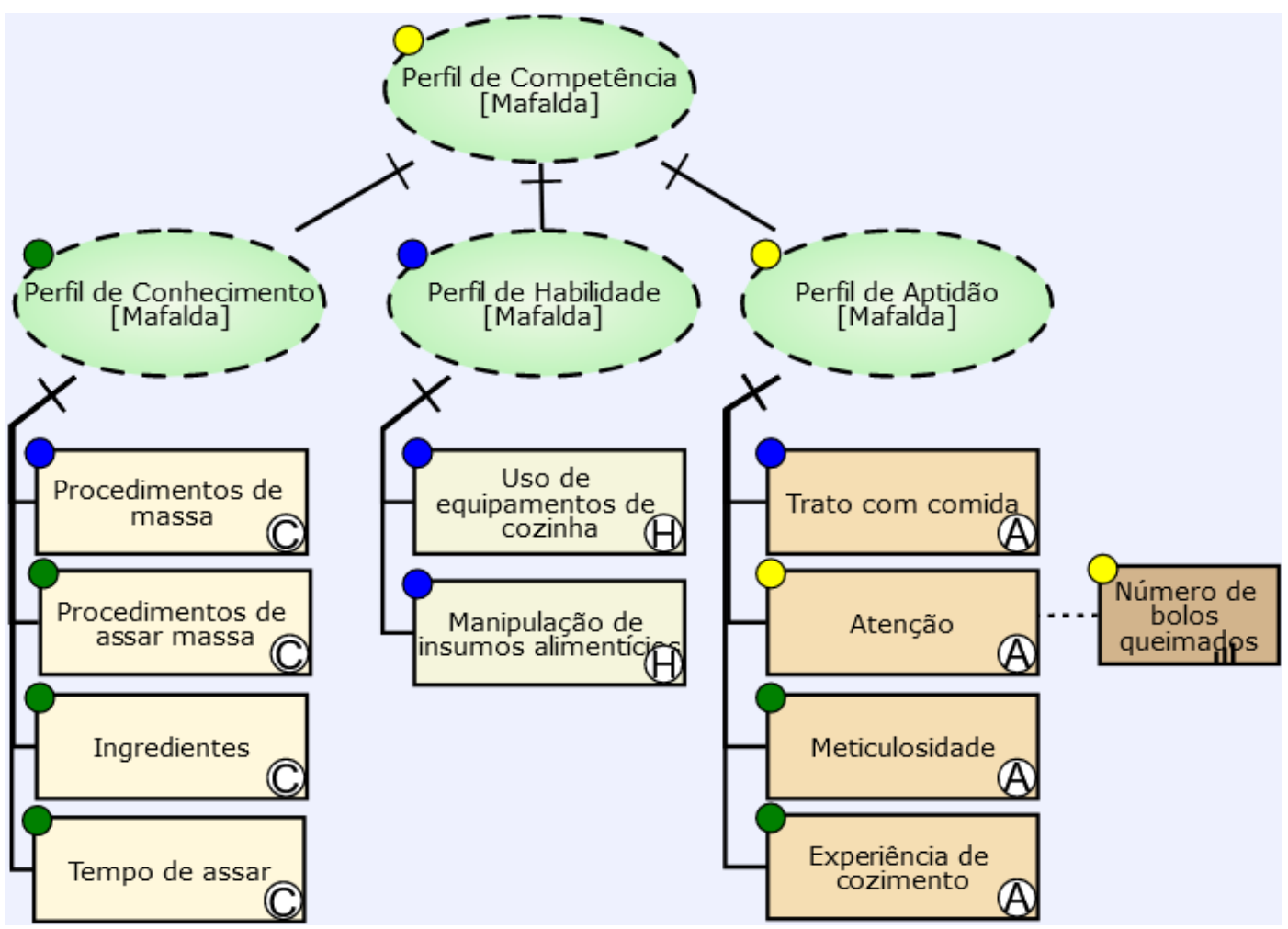

Figura 2.9. Perfil Real da Sra. Mafalda.

O indicador "Número de bolos queimados" demonstra que a Sra. Mafalda não tem apresentado bons resultados, ainda que seja tolerado essa falha. Isso denota (segundo o modelo) falta de atenção. É possível que a Sra. Mafalda esteja desatenta durante o cozimento, o que tem gerado resultados inconvenientes, como a queima do bolo.

Entretanto, nos outros elementos CHA a Sra. Mafalda possui excelente avaliação. Na propagação dos marcadores, o Perfil de conhecimento ficou verde; o Perfil de habilidade, azul; e o Perfil de Aptidão, amarelo. O valor amarelo do Perfil de Aptidão é proveniente da avaliação do indicador, que propagou para a Aptidão Atenção, também propagando para o Perfil de Aptidão, considerando que este é o pior caso neste perfil. Entre os perfis (verde, azul e amarelo), a propagação também foi feita com o marcador amarelo para o Perfil de Competência, sendo esta a avaliação de Alinhamento de RH da Sra. Mafalda.

\subsection{Modelagem de Processos}

Os processos apresentam uma sequência temporal de tarefas que devem ser realizadas de forma satisfatória para que, ao final da execução do processo, o(s) objetivo(s) o(s) qual(is) ele se propõe(m) alcançar, seja(m) alcançado(s).

A linguagem GPI-HR reutiliza alguns dos elementos de notação da BPMN [OMG, 2011], bem como personaliza outros para representar novos conceitos, por exemplo, a tarefa e processo especializado.

Para exemplificar a modelagem de um processo, utilizaremos uma notação simplificada contendo apenas os conceitos fundamentais, descritos na Tabela 2.5:

Tabela 2.5. Notação simplificada para modelagem de processos. 


\begin{tabular}{|l|l|}
\hline & $\begin{array}{l}\text { Uma tarefa representa uma ação que demanda competências humanas } \\
\text { comuns à formação geral relacionada ao papel organizacional. }\end{array}$ \\
\hline $\begin{array}{c}\text { Evefa } \\
\text { Evento } \\
\text { final }\end{array}$ & $\begin{array}{l}\text { Entradas e saídas de tarefas que podem representar elementos físicos, } \\
\text { como um produto, ou abstrato, como uma informação. } \\
\text { fluxos sequenciais de um processo. }\end{array}$ \\
\hline $\begin{array}{c}\text { Evento } \\
\text { intermediário }\end{array}$ & $\begin{array}{l}\text { Eventos expressam fatos que ocorrem durante a execução de um processo. } \\
\text { Pode ser classificado em evento inicial, intermediário e final. }\end{array}$ \\
\hline
\end{tabular}

O processo a ser modelado prossegue no tema de "Fazer bolo", aplicado ao modelo de competências apresentado anteriormente. Utilizamos uma descrição simples de receita de bolo, obtida em uma busca no google ${ }^{1}$. Os passos são transcritos a seguir:

1. Bata as claras em neve e reserve.

2. Misture as gemas, a margarina e o açúcar até obter uma massa homogênea.

3. Acrescente o leite e a farinha de trigo aos poucos, sem parar de bater.

4. Por último, adicione as claras em neve e o fermento.

5. Despeje a massa em uma forma grande de furo central untada e enfarinhada.

6. Asse em forno médio $180{ }^{\circ} \mathrm{C}$, preaquecido, por aproximadamente 40 minutos ou ao furar o bolo com um garfo, este saia limpo.

Nosso exercício resultou no modelo apresentado na Figura 2.10.

A modelagem, de uma forma geral, possui desafios intrínsecos, especialmente quanto a completude das informações. Observamos que textualmente o processo de "Fazer bolo" é apresentado em 6 linhas. No entanto, ao formalizar o processo através de uma linguagem de modelagem, observa-se que há muitos detalhes implícitos. Este caso apresenta bem a importância do uso do modelo para formalizar os procedimentos e seus pormenores de tal forma que seja obtido o "algoritmo" de realização do processo. Não obstante, a modelagem de processo utiliza elementos como operadores lógicos e eventos para demonstrar as possibilidades e diferentes caminhos que podem ser seguidos dentro de uma instancia de processo.

Por mais simplória que seja a informação escrita no site, uma série de insumos e produtos parciais são administrados durante a execução do processo. A formalização em um modelo auxilia a identificar os detalhes de cada tarefa e, eventualmente, identificar ausência e/ou inconsistências de informações. O entendimento do modelador em relação às informações de origem também pode afetar o modelo final.

\footnotetext{
${ }^{1}$ Resultado utilizado: https://www.tudogostoso.com.br/receita/29124-bolo-simples.html
} 


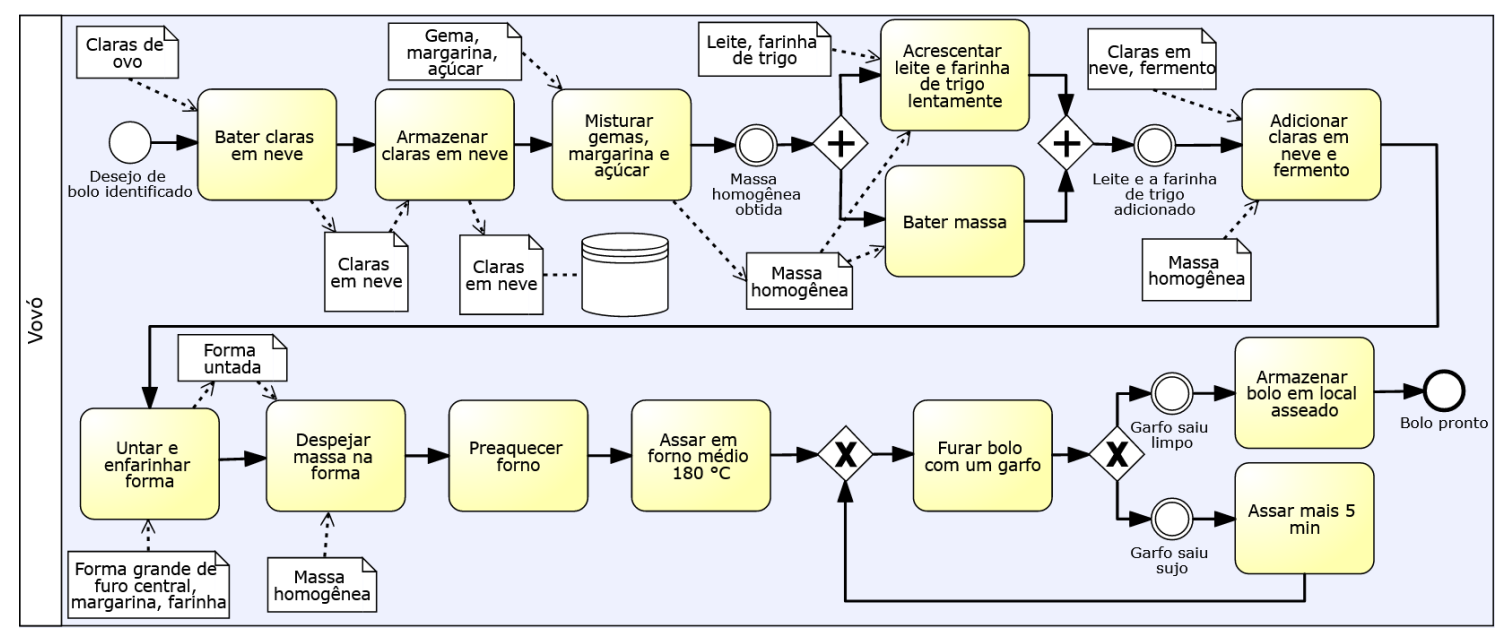

Figura 2.10. Exemplo de processo "Fazer bolo".

\subsubsection{O Perfil Requerido em Diferentes Tarefas/Processos}

Um processo é composto por tarefas atômicas que podem realizadas por recursos humanos. Cada tarefa possui o seu grau de complexidade e importância aos objetivos organizacionais, demandando diferentes perfis profissionais para aquele que for realizála.

Em geral, papéis organizacionais demandam um perfil profissional específico, o qual se define por diversas competências básicas na sua formação (ex. médico e engenheiro). Entretanto, existem tarefas que podem demandar especializações diversas que se destacam do que é considerado básico. Normalmente são tarefas mais complexas e sensíveis, que oferecem o risco de gerar problemas à execução do processo caso sejam negligenciadas ou realizadas de forma insatisfatória. Os impactos dependem da relação do produto destas tarefas com o resultado do processo, ou ainda, com a importância de seus resultados à indicadores importantes.

Baseado nisso, são usados os conceitos de Tarefas Gerais e Tarefas Especializadas. As Tarefas Gerais demandam perfil de competência similar, intrínseco à todas as tarefas comuns. As Tarefas Especializadas demandam maior refinamento de competências, por exemplo, devido ao seu grau dificuldade, riscos, especialização, importância estratégica. De forma geral, a Tarefa Especializada apresenta algo que justifica a diferenciação na seleção de determinado recurso humano o qual irá se responsabilizar pela tarefa.

A modelagem do Perfil Requerido destes dois tipos de tarefas é necessária para definir os requisitos em que o ator organizacional demandará na expectativa que suas responsabilidades possam ser satisfeitas e, consequentemente, seus objetivos serem atingidos.

O Perfil Requerido das Tarefas Gerais será potencialmente suprido pela formação geral demandada pelo ator organizacional. O Perfil Requerido das Tarefas Especializadas é especialmente elaborado para este tipo de tarefa. A expectativa é que cada Tarefa Especializada tenha seu conjunto de requisitos específicos, para que seja avaliada especificadamente na questão do alinhamento de RH.

Por exemplo, para uma Tarefa Especializada de decisão estratégica, o entendimento da estratégia é fundamental, uma vez que uma decisão desfavorável poderia resultar em um desalinhamento de maior risco à organização. Nestes casos, observa-se que o Perfil Requerido da tarefa deve ser modelado registrando como quesito maior nível de indicação do entendimento da estratégia do que no Perfil Requerido das 
Tarefas Gerais. Assim, considera-se que o recurso humano que for alocado para a realização de uma Tarefa Especializada deve estar mais qualificado e seja capaz de concretizar a tarefa de forma satisfatória.

A literatura de RH também aborda a definição da complexidade em tarefas e postos de trabalho. Para [Dutra, 2007], a diferenciação de níveis de complexidade permite perceber com maior nitidez o processo de desenvolvimento das pessoas e o levantamento de necessidades de treinamento de maneira mais aproximada da realidade de trabalho e, portanto, de maneira mais precisa. Maia (2011) define o conceito de nível de entrega, que determina a intensidade mínima requerida para um determinado posto de trabalho, o que permite traçar trilhas de aprendizagem de acordo com os seus objetivos de carreira.

Apesar das indicações de alinhamento de $\mathrm{RH}$, nem sempre é possível ter o recurso humano competente disponível. A decisão de alocar um recurso humano com qualificação menor à demandada torna-se um elemento de decisão da organização e um indicativo de risco, ainda que os resultados alcançados sejam satisfatórios.

\subsubsection{Exemplo de Tarefa Especializada}

Considerando o processo de "Fazer bolo" descrito na Figura 2.10, alteramos, para exemplificar, a tarefa "Assar em forno médio a $180^{\circ} \mathrm{C}$ ” para “Assar massa em forno industrial de lastro” (Figura 2.8).

Ao se inserir esse tipo de tecnologia industrial, obrigatoriamente se faz necessário rever o conjunto de requisitos de competências necessários para implementar este processo já que agora é exigida a capacidade de operar adequadamente um forno industrial do tipo "de lastro". Portanto, há uma tarefa que demanda um perfil mais específico, com especialidade na operação deste forno. Isso foge ao currículo genérico de pessoas que se propõem a fazer bolo.

Para diferenciar esses processos/tarefas, a notação é alterada (Tabela 2.6 e Figura 2.11) pela cor, e há a expectativa de existir um Perfil Requerido específico para estes processos/tarefas, tanto para identificar os CHAs específicos, mas especialmente para permitir a avaliação de alinhamento de $\mathrm{RH}$ em separado dos processos/tarefas gerais.

Tabela 2.6. Notação específica para processos/tarefa complexa/especializada.

\begin{tabular}{|l|l|}
\hline $\begin{array}{c}\text { Tarefa } \\
\text { Complexa/ } \\
\text { Especializada }\end{array}$ & $\begin{array}{l}\text { Uma tarefa complexa/especializada representa uma tarefa que demanda } \\
\text { competências humanas específicas para que seja realizada de forma } \\
\text { satisfatória. }\end{array}$ \\
\hline $\begin{array}{c}\text { Processo } \\
\text { Complexo/ } \\
\text { Especializado } \\
\text { f }\end{array}$ & $\begin{array}{l}\text { Um processo complexo/especializado é composto por tarefas que } \\
\text { demandam competências humanas específicas para que seja realizada de } \\
\text { forma satisfatória. }\end{array}$ \\
\hline
\end{tabular}

Esses processos/tarefas especializadas podem representar também partes críticas na organização, as quais devem ser acompanhadas. Por exemplo, tarefas vinculadas a objetivos estratégicos, ou tarefas sensíveis que estão diretamente relacionadas ao desempenho. 


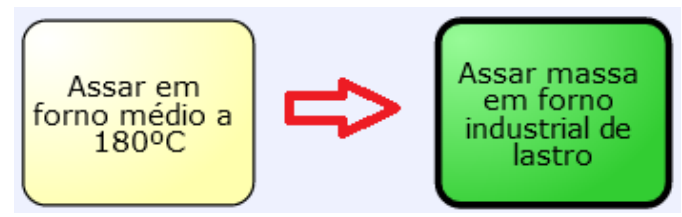

Figura 2.11. Mudança de tipo de tarefa, geral para especializada.

\subsubsection{Relacionando Perfis, Tarefas, Processos, Competências e Objetivos}

Conforme apresentado na seção 2.2.2, tarefas/processos são um meio de se entregar competências, e as competências são um meio de se satisfazer objetivos (Figura 2.6). Nesta sessão descrevemos como essas relações ocorrerem nos modelos de processos.

$\mathrm{Na}$ seção anterior, afirmarmos que em um modelo de processo existem transformações nos artefatos que são processados em suas tarefas. Quanto mais complexo um processo, maior a possibilidade que ele tenha produtos parciais. Esses produtos parciais são bem definidos por indivíduos que conhecem o domínio para o qual ele se aplica. Cada trecho de um processo pode representar algo com semântica bem definida, e denotar um ponto em que se pode afirmar que algo foi alcançado. Identificar essas partes é importante para que se entenda melhor o funcionamento do processo, e isso permitirá analisá-lo de forma mais aprofundada.

Todo processo é definido com pelo menos um objetivo. Esse objetivo pode ser decomposto em subobjetivos se for possível também delinear trechos bem definidos de um processo, uma vez que são estes trechos que implementam os subobjetivos. Nos casos em que um único processo é relacionando a dois ou mais objetivos, fica a pergunta: todos os objetivos são alcançados somente ao fim da instância do processo ou eles são alcançados em momentos diferentes durante a execução do processo?

Pontuar cada objetivo e sua relação exata com as tarefas de um processo é um passo importante que irá manter um rastro mais aprofundado, o que consequentemente permitirá identificar as tarefas que estão vinculadas a ele, bem como os atores, artefatos, indicadores e, especialmente na linguagem GPI-HR, a relação com os Perfis de Competência, ou seja, os requisitos de RH.

Para demarcar trechos de um processo, a linguagem GPI-HR utiliza um elemento de agrupamento (agroupment) que agrupará os elementos de um processo que são implementados para satisfazer determinado subobjetivo do processo. Seguindo a relação orientada por competências, o trecho irá entregar uma competência de menor valor agregado, porém, bem definida.

A Figura 2.12 apresenta o processo de "Concessão de empréstimo" contendo quatro agrupamentos que são vinculados especificamente as competências que entregam e, por sua vez, as competências se relacionam aos objetivos que satisfazem. 


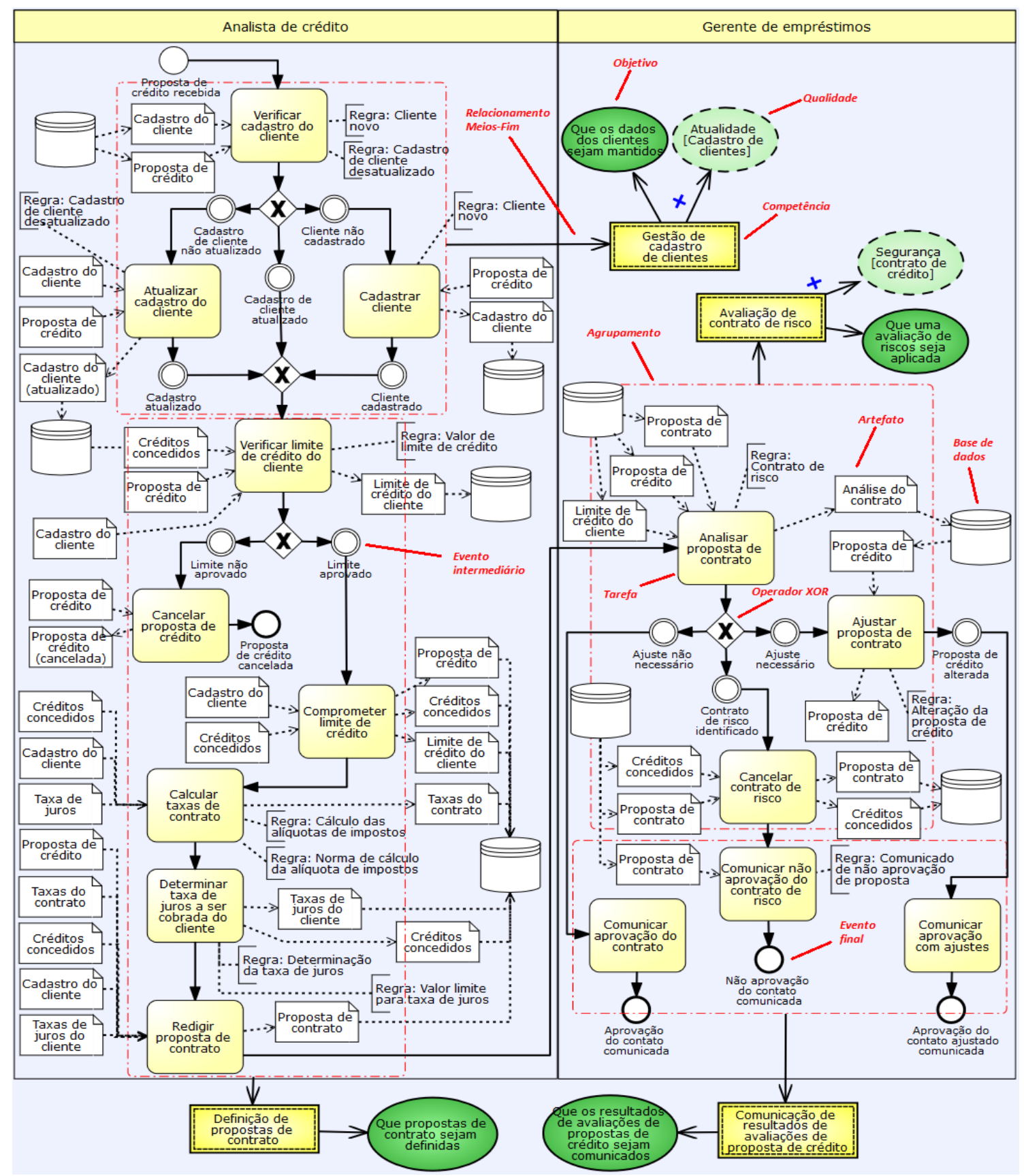

Figura 2.12. Processo "Concessão de empréstimo".

Este processo mais “robusto” e “detalhado” é apresentado como exemplo mais completo para demonstrar o uso da linguagem GPI-HR no nível de processos.

A “decomposição do processo" permite isolar partes para permitir sua análise. A figura 2.13 apresenta o Perfil de Competência Requerido instanciado apenas para a competência "Definição de propostas de contrato".

Eventuais problemas na entrega dessa competência podem ser investigados através da sua relação com as tarefas específicas que a implementam, bem como na avaliação do Perfil Real que estará vinculado a esta competência. 


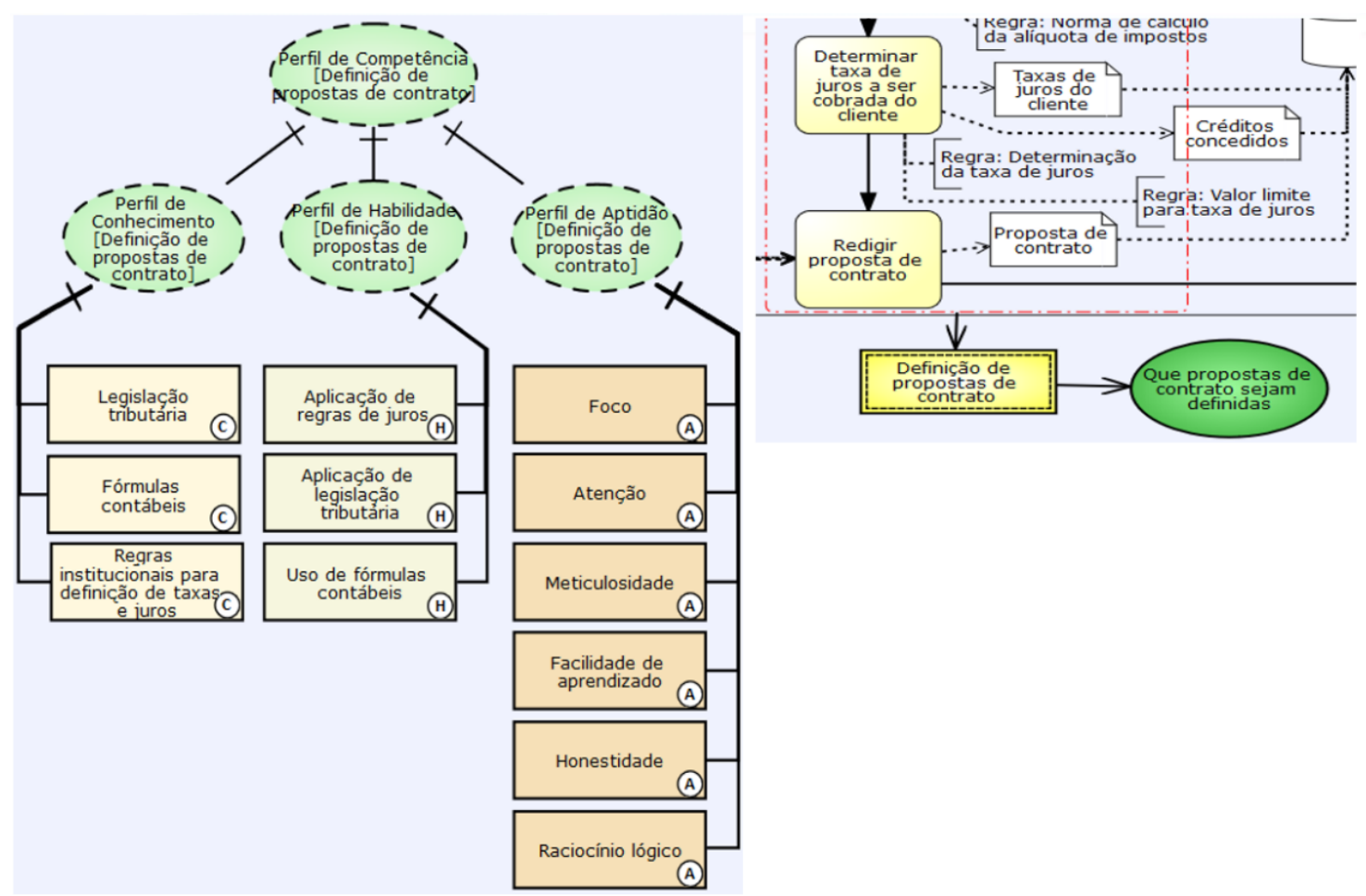

Figura 2.13. Exemplo de processo "Fazer bolo".

\subsection{Estratégia}

O conceito de estratégia é discutido na literatura sob diversos aspectos, tornando o conceito amplo e diversificado. Segundo [Mckeown, 2019] "estratégia é moldar o futuro - é como as pessoas alcançam o fim desejável com os meios disponíveis”. Entretanto, projetar o futuro significa lidar com incertezas. Projetar cenários hipotéticos está vinculado a planejar ações de forma antecipada, visando lidar da melhor forma possível com as mudanças de contexto.

Segundo a visão apresentada na linguagem i* por [Yu, 1994], a estratégia é definida pelo raciocínio (reasoning) de um ator para se alcançar elementos de uma forma intencional. O raciocínio mencionado por $\mathrm{Yu}$ se refere a descrição de um conjunto de elementos intencionais, que delineiam diferentes caminhos, os quais configuram meios de implementação para se alcançar objetivos.

Sob a ótica organizacional, as organizações definem estratégias como uma forma de sobrevivência, uma vez que normalmente se encontram em mercados competitivos. Uma boa estratégia pode permitir que as empresas alcancem posições de vantagem em relação aos seus concorrentes.

\subsubsection{A Estratégia e a Camada Estratégica de uma Organização}

Organizações são normalmente divididas nas camadas estratégica, tática e operacional. Essa divisão em camadas cria uma linha fictícia que representa uma hierarquia decisória.

A camada estratégica visa delinear os caminhos que a organização deve seguir, o que normalmente são decisões de longo prazo, tomadas por indivíduos do alto escalão de gerência da empresa. A camada tática é intermediária, e normalmente se responsabiliza por decisões de médio prazo, sendo ainda uma camada gerencial que define responsabilidades para a camada operacional. A camada operacional é responsável pela implementação dos processos de produção da organização. 
Vulgarmente conhecida como "chão de fábrica”, toma decisões de curto prazo, visando normalmente manter os processos em execução. Pode ter uma parte gerencial, por exemplo, composta de líderes/coordenadores de equipe.

Apesar desta relação hierárquica, em todas as camadas pode (e deve) haver estratégia. Por exemplo, na camada operacional, no setor de vendas, um recurso humano pode implementar as suas estratégias de venda, visando obter bom desempenho. Uma equipe médica pode traçar um plano estratégico de tratamento, visando curar determinada doença.

Portanto, o conceito de estratégia não deve ser confundido com o de camada estratégica. Todos os papéis organizacionais podem implementar estratégias para alcançar seus objetivos.

\subsubsection{Modelando a Estratégia}

As estratégias são definidas a partir de objetivos centrais. Por exemplo, no nível organizacional, os objetivos estratégicos são definidos a partir dos objetivos primários de qualquer organização chamados de visão e missão, sendo a visão um objetivo de longo prazo, e a missão um objetivo mais imediato. Tudo o que se prossegue destes elementos são decomposições de objetivos em outros objetivos menos abstratos, os quais serão vinculados, em algum momento, aos departamentos como suas responsabilidades. Estes, por sua vez, irão desdobrar suas metas pela estrutura que administram até alcançar objetivos mais concretos, ligados aos elementos que os implementam (por exemplo, tarefas, processos, competências - comumente chamados de operacionalização).

Na literatura de modelagem organizacional, a possibilidade de se escolher entre diferentes formas de operacionalização é chamada de "variabilidade" [Liaskos et al., 2007]. A variabilidade é considerada um aspecto positivo porque oferece diferentes possibilidades que possuem características próprias e são melhor adequadas a diferentes circunstâncias.

Neste minicurso, exemplificaremos casos mais simples para facilitar o entendimento. Portanto, iniciaremos a modelagem da estratégia a partir de um objetivo.

Ao se definir um objetivo surgem questões que devem ser respondidas para se traçar possíveis planos capazes de satisfazê-lo. Por exemplo, "Como alcançar esse objetivo?”, "Existem outras formas de satisfazer este objetivo?”, O que é necessário para se alcançar este objetivo?”, “Os recursos estarão disponíveis?”, “Existem pontos fracos ou ameaças que podem atrapalhar a satisfação deste objetivo?”, "Existem pontos fortes ou oportunidades que poderão apoiar a satisfação deste objetivo". Estas e inúmeras outras perguntas podem ser feitas na projeção de operacionalizações para o objetivo.

Eventualmente, o conhecimento elencado irá permitir a definição operacionalizações de qualidade, que possuem características distintas que as caracterizarão como opções mais ou menos adequada a diferentes circunstâncias.

\subsubsection{Exemplo - Modelando Possíveis Operacionalizações e Situações de Contexto}

Na linguagem GPI-HR existe um relacionamento específico, proveniente do reuso da linguagem $i^{*}$ que se chama meios-fim (means-end) [Yu, 1994].

O relacionamento de meios-fim liga um ou mais elementos primários que representam caminhos possíveis (meio) para se alcançar um elemento secundário, que representa o alvo (fim) desejado. A decisão pela realização do "meio" caracteriza a 
intenção de se alcançar o "fim". Na abordagem orientada a competências, as competências são os meios definidos para se alcançar os objetivos da organização, definidos como fim.

O relacionamento de meios-fim é representado por uma seta simples, com ponta aberta e alongada (Figura 2.14).

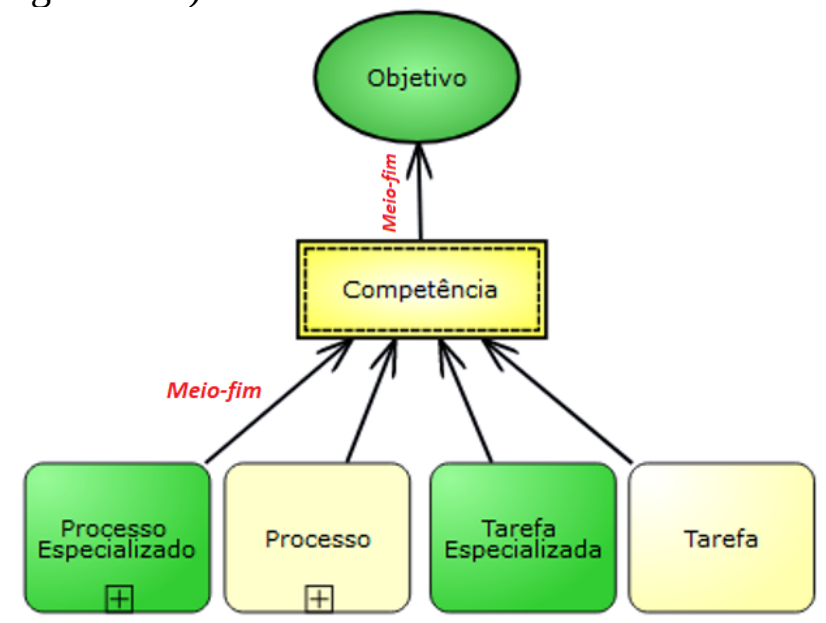

Figura 2.14. Exemplo conceitual do relacionamento de meios-fim (means-end).

A representação de múltiplos relacionamentos meios-fim expressa a variabilidade de operacionalizações para determinada competência, ou seja, existem diferentes formas de se alcançar a entrega de uma mesma competência. A partir do conceito de variabilidade é que se avaliam os melhores caminhos a se seguir, considerando as diferentes características das variações como contribuição de qualidades e adaptação ao contexto.

Na figura 2.15 apresentamos três exemplos de variabilidade de operacionalizações.

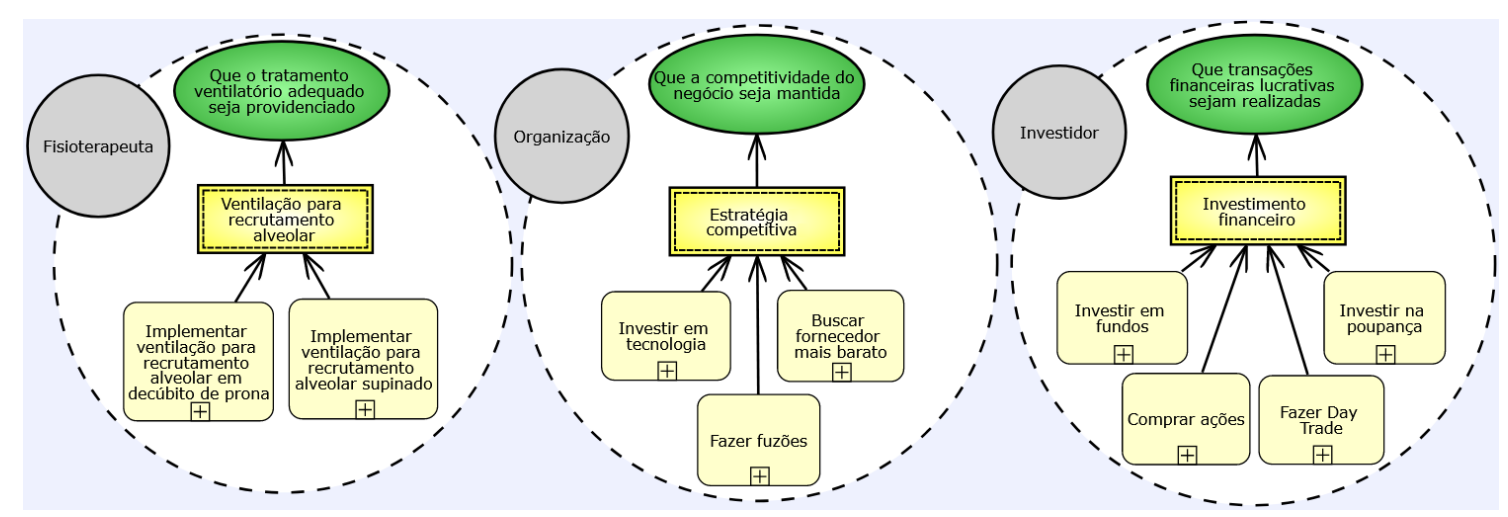

Figura 2.15. Exemplo de variabilidade de operacionalizações.

No primeiro exemplo, o Fisioterapeuta possui o objetivo "Que o tratamento ventilatório adequado seja providenciado”. Para satisfazer esse objetivo foi definida a competência "Ventilação para recrutamento alveolar", a qual pode ser entregue a partir da implementação de duas operacionalizações (no caso, dois processos) que são: Implementar ventilação par recrutamento alveolar em decúbito de prona” e "Implementar ventilação para recrutamento alveolar supinado".

No segundo exemplo, a Organização possui o objetivo "Que a competitividade do negócio seja mantida". Para satisfazer esse objetivo é necessário que a competência estratégia competitiva seja entregue. Três possíveis operacionalizações para essa 
competência estão previstas: "Investir em tecnologia", "Buscar fornecedor mais barato" e "Fazer fusões".

No terceiro exemplo, o Investidor possui o objetivo "Que transações financeiras lucrativas sejam realizadas". Para satisfazer esse objetivo é necessário que a competência "Investimento financeiro" seja entregue. As operacionalizações possíveis são: "Investir em fundos", "Comprar ações", "Fazer Day Trade" e "Investir na Poupança".

As operacionalizações descritas apresentam diferentes formas de se implementar a competência. Cada operacionalização irá demandar um conjunto de requisitos próprios que podem diferenciar bastante o esforço de implementação, bem como o resultado.

Para se identificar qual a melhor operacionalização possível, há de se observar quais são as circunstâncias nas quais elas são melhor aplicáveis. Isso é o elemento central para a projeção de estratégias: identificar os possíveis estados de variáveis do ambiente para caracterizar situações para as quais determinadas operacionalizações são mais interessantes de se aplicar.

Em nosso exemplo, apresentamos primeiramente os conceitos presentes na definição da variabilidade (Figura 2.14 e Figura 2.15), entretanto, para a definição da estratégia, a avaliação de cenários e definição/adaptação de ações ocorrem da forma que for mais conveniente para a organização. As operacionalizações estratégicas devem ser intencionalmente definidas para lidar com situações do mundo real, as quais se alteram ao longo do tempo, demandando adaptações.

$\mathrm{Na}$ Administração, é comum a separação do ambiente interno e do ambiente externo para o estudo de possíveis cenários. $\mathrm{O}$ ambiente externo se torna mais relevante de se observar porque é onde ocorrem mudanças, as quais a organização não possui nenhum controle e que, possivelmente, irão requerer alguma adaptação. O ambiente interno abrange todo domínio da organização, em especial, os elementos que compõem a sua estrutura.

No entanto, é importante identificar o conjunto de elementos que se relacionam ao domínio que está sendo tratado, e que são capazes de influenciar de alguma forma a estratégia. O mapa desses elementos (elementos do contexto) delineia o contexto da estratégia, o que inclui o ambiente externo e interno.

As situações possíveis dentro de um contexto (situação de contexto) devem ser tratadas de forma estratégica através de operacionalizações

$\mathrm{Na}$ figura 2.16, foram incluídas as situações de contexto às respectivas operacionalizações. 


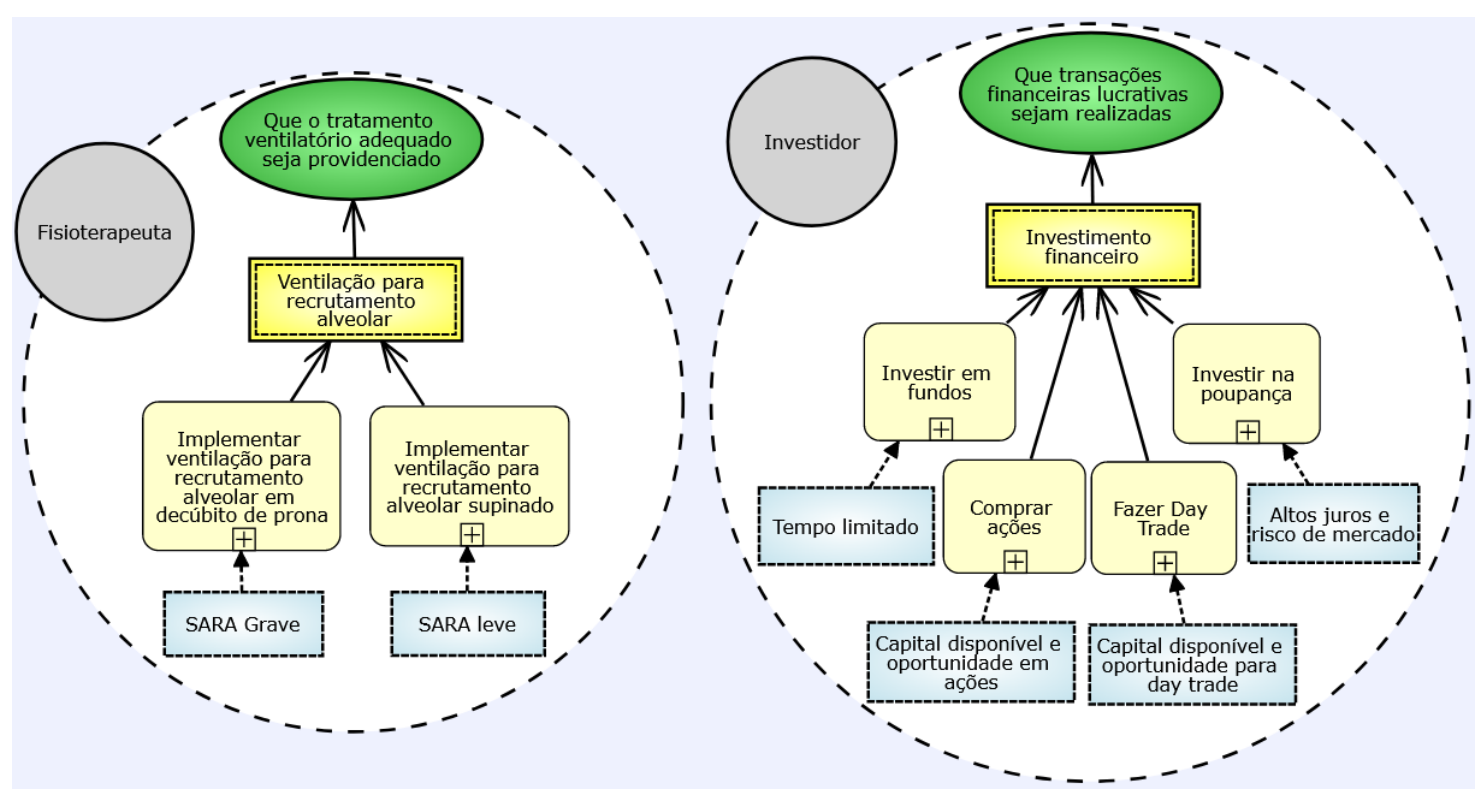

Figura 2.16. Exemplo de situações de contexto vinculadas a operacionalizações.

As situações de contexto "sugerem" a implementação das operacionalizações as quais estão vinculadas porque entende-se que estas operacionalizações foram planejadas de forma a conduzir ao melhor desempenho possível naquela situação.

\subsubsection{Modelando as Situações de Contexto}

O contexto é composto por um conjunto de elementos que estão direta e/ou indiretamente envolvidos em determinado domínio. O que define o contexto é, em última análise, o universo do discurso [Leite et al., 2007].

Os elementos de um contexto podem ser neutros, ou capazes de interferir positivamente ou negativamente para outros elementos ou questões do domínio. Uma forma de facilitar a análise de contexto, é apenas considerar os elementos que podem causar interferência no domínio delimitado. A partir do mapeamento desses elementos, da avaliação de seus possíveis estados e respectivas contribuições, podem ser avaliadas possíveis situações no tempo. Isso permite a previsão de ações tendo em vista o melhor desempenho e/ou a redução de perdas.

O contexto é uma contribuição importante na tomada de decisões porque pode indicar momentos favoráveis ou desfavoráveis para realizar determinadas ações, ajudando na orientação organizacional. As situações de um contexto podem expressar o estado atual das coisas ou ser hipotéticas, com base em condições que, quando reais, indicam a vantagem ou a desvantagem em caminhos estratégicos. Por exemplo, a avaliação do contexto pode ajudar a decidir sobre investimentos e o redirecionamento de esforços para seguir melhores estratégias.

Na modelagem de processos (nível operacional), as situações de contexto podem ser caracterizadas pelos diferentes estados alcançados, os quais orientam o processo em diferentes direções [Santos et al., 2011]. Entretanto, no âmbito estratégico, inúmeras variáveis internas ou externas à organização podem ser importantes, sendo essencial mapeá-las em um modelo específico que auxilie a expressar os elementos, seus estados e relações.

Considerando a complexidade no mapeamento dos elementos de contexto e na compreensão de como eles interagem com outros elementos, a linguagem GPI-HR utiliza um padrão para modelagem de contexto, considerando elementos já presentes na 
linguagem (participantes do domínio que é expresso), seus estados e classificação de acordo com expectativas em uma avaliação de contexto.

Os componentes da linguagem GPI-HR definem os conceitos do domínio que podem ser modelados. Esses elementos delimitam o escopo dos conceitos do mundo real. Se o padrão for aplicado em outras linguagens, esses elementos devem ser revistos para os conceitos abordados na determinada linguagem.

Considerando a linguagem GPI-HR, identificamos os seguintes elementos que podem ser mapeados no contexto: a) indicadores (de qualquer natureza) que podem representar os valores das diferentes características dos elementos no contexto, b) o estado dos negócios, representando estados gerais não mensuráveis por indicadores, por exemplo, estados alcançados por uma instância de processo, c) estado dos recursos, representando a disponibilidade ou não de qualquer tipo de recursos, d) qualidade, representando a satisfação ou não de qualidades, que podem expressar pontos fortes e fracos, e) metas, representando metas cumpridas ou não e f) situações de contexto, representando sub contextos ou contextos relacionados que devem ser prioritariamente verdadeiros ou falsos.

Os recursos humanos também são variáveis do contexto e poderiam ser representados no modelo de contexto, entretanto, o GPI-HR apresenta recursos específicos para sua avaliação. Portanto, não os incluímos expressamente no modelo.

O modelo de contexto é genérico, apresentando o total de variáveis mapeadas ao contexto estratégico. Uma situação de contexto é uma instância deste modelo, normalmente caracterizada por um número limitado de elementos do ambiente que estão relacionados a uma estratégia e seus respectivos valores.

Portanto, o contexto é formado por um conjunto de elementos:

- Contexto \{Elemento A, Elemento B, Elemento C...\}

Sendo que cada elemento pode tomar um conjunto de valores no tempo:

- Elemento A \{valor1, valor2, valor3...\}

E a situação de contexto é caracterizada por um conjunto de elementos e seus respectivos valores caracterizados na determinada situação:

- Situação do contexto \{(ElementoA, valor2), (ElementoB, valor1), ... $\}$

Num contexto podem se estabelecer inúmeras situações de contexto.

O padrão de modelagem de contexto permite a classificação dos elementos do contexto. Essa classificação permite ampliar a possibilidade de registro de variáveis que estão vinculadas a situação de contexto de uma forma qualitativa positiva ou negativa, não sendo responsáveis por caracterizar o contexto, mas podem influenciar de alguma forma.

Registrar elementos de influência pode auxiliar a análise estratégica e a avaliação de situações do contexto, já que a influência destes elementos pode ser diversa, o que amplia o escopo de análise. Podem representar expectativas além do que se caracteriza como contexto favorável, ou apresentar pontos de atenção.

Os elementos do contexto podem ser classificados de acordo com quatro estados: mandatório ser verdadeiro, mandatório seja falso, desejável ser verdadeiro, desejável ser falso. Os elementos " mandatório ser verdadeiro" são necessários no contexto esperado, enquanto os elementos "obrigatórios sejam falsos" são proibidos. Os 
elementos "desejáveis ser verdadeiro" contribuem positivamente para o contexto desejado, enquanto os elementos "desejáveis ser falso" contribuem negativamente.

A figura 2.17 apresenta o padrão de modelagem de contexto.

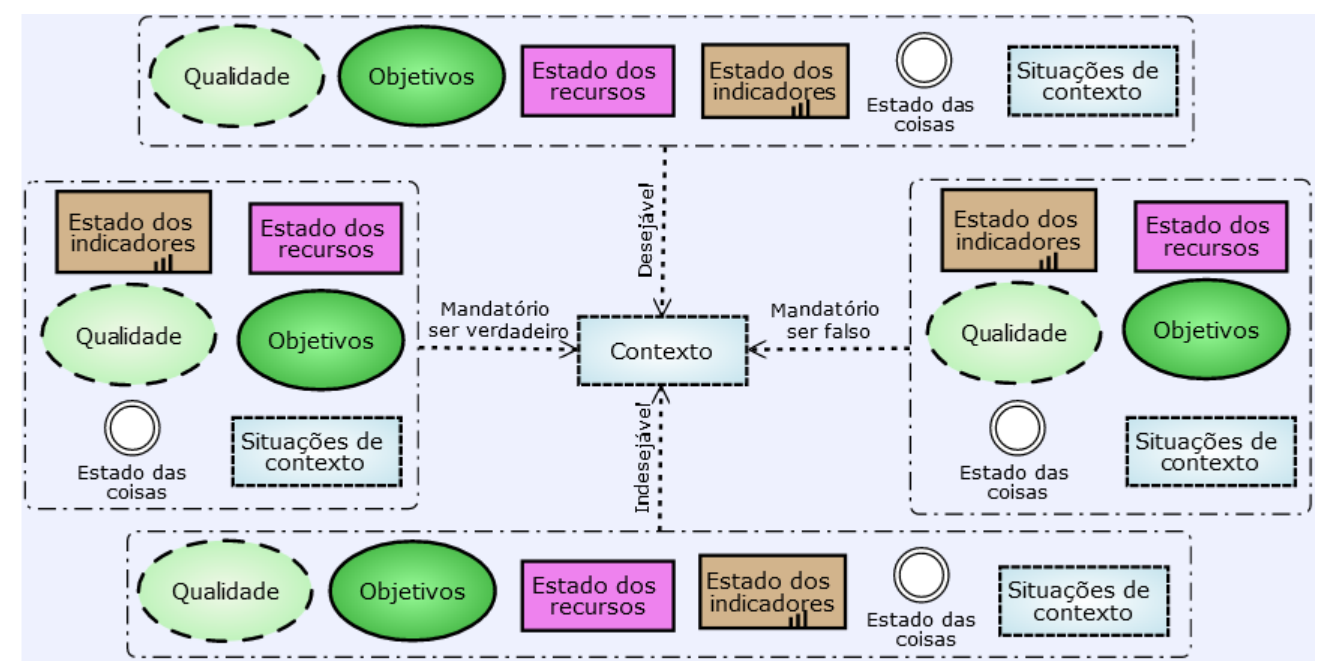

Figura 2.17. Padrão de modelagem de contexto.

\subsubsection{Exemplo - Situações de Contexto}

A Figura 2.18 apresenta um exemplo de modelagem da situação de contexto SARA grave, inicialmente apresentada na Figura 2.16.

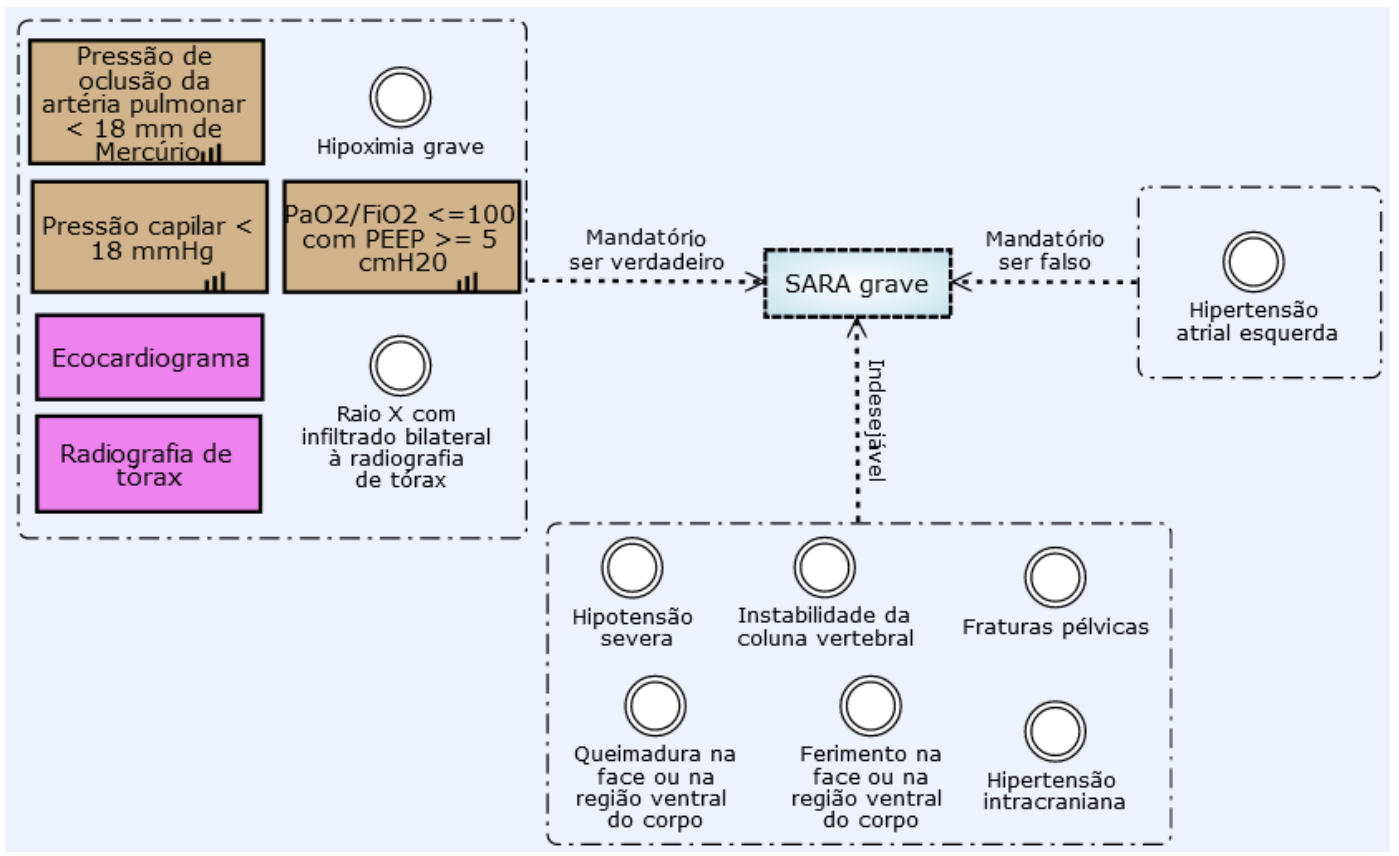

Figura 2.18. Situação de Contexto "SARA grave", sem marcadores.

Particularmente, este contexto é composto pelos elementos obrigatórios (mandatórios) e um conjunto de estados indesejáveis. Neste caso, os elementos obrigatórios caracterizam o estado avançado da SARA (Síndrome da Angústia Respiratória Aguda). Os elementos indesejáveis não estão relacionados ao estado da doença, porém são indesejáveis pois irão dificultar o tratamento adequado, eventualmente demandando outros cuidados paralelos.

Este modelo representa apenas o mapa conceitual da situação de contexto SARA grave. Para se observar sobre o estado desta situação de contexto, é necessário 
identificar os estados de todas as variáveis mapeadas. Para isso, são aplicados os marcadores no modelo.

\subsubsection{O Uso de Marcadores nos Elementos do Contexto}

Os elementos do contexto podem apresentar diferentes valores ao longo do tempo. Entretanto, para caracterizar uma situação do contexto, o intervalo dos elementos do contexto deve ser estabelecido. Após estabelecer os valores que caracterizam determinado elemento do contexto sob determinada situação, a sua avaliação torna-se binária, sendo verdadeira se seu valor estiver no intervalo ou falso, se estiver fora do intervalo.

Alguns elementos podem não ser caracterizados por um intervalo de valor, porém possuem estados bem definidos. Por exemplo, um objetivo, pode estar satisfeito ou não. Se satisfeito, ele denota uma variável do contexto em que seu estado é verdadeiro. Caso contrário, o seu estado é falso.

No caso dos recursos necessários para determinada situação de contexto, avaliase a sua presença, o que caracteriza um estado verdadeiro, ou ausência, caracterizando o estado falso.

Os eventos/estados já possuem a sua característica binária. As situações de contexto, ou são verdadeiras ou falsas.

Os elementos do contexto são classificados conforme mostra a Tabela 2.8.

Tabela 2.8. Marcadores para elementos do contexto.

\begin{tabular}{|c|l|}
\hline Marca & Semântica \\
\hline$\bigcirc$ & O estado do elemento é verdadeiro. \\
\hline$\bigcirc$ & O estado do elemento é falso. \\
\hline
\end{tabular}

\subsubsection{O Uso de Marcadores na Situação de Contexto}

Após definidos os marcadores dos elementos do contexto, é possível definir o marcador final da situação de contexto de acordo com o descrito na Tabela 2.7:

A Figura 2.19 apresenta um exemplo em que a SARA grave é uma situação real no contexto. Todos os elementos "Mandatório ser verdadeiro" estão marcados como verdadeiro (verde); todos os elementos "Mandatório ser falso" estão marcados como falso (vermelho); nos elementos indesejáveis, o estado de Fraturas Pélvicas é verdadeiro, indicando que há um elemento indesejável que está presente no contexto.

A presença deste elemento indesejável, define o marcador amarelo na situação de contexto, denotando que "O contexto é favorável à ação, mas deve ser verificado em termos de riscos potenciais de elementos indesejáveis com potencial contribuição negativa”.

A implicação estratégica da situação de contexto vai depender de outras variáveis presentes no modelo principal (Figura 2.16), onde o marcador amarelo irá propagar. 
Tabela 2.7. Marcas para situação do contexto.

\begin{tabular}{|l|l|}
\hline Marca & Semântica \\
\hline & $\begin{array}{l}\text { O contexto tem: } \\
\text { Todos os elementos "obrigatório ser verdadeiro", verdade; } \\
\text { Todos os elementos "desejáveis", verdade; } \\
\text { Todos os elementos "indesejáveis", falsos; } \\
\text { Todos os elementos "obrigatório ser falso", falsos. } \\
\text { O contexto é totalmente favorável à ação. }\end{array}$ \\
\hline $\begin{array}{l}\text { O contexto tem: } \\
\text { Todos os elementos "obrigatório ser verdadeiro", verdade; } \\
\text { Nenhum ou alguns elementos "desejáveis", verdade; } \\
\text { Todos os elementos "indesejáveis", falsos; } \\
\text { Todos os elementos " obrigatório ser falso", falsos. } \\
\text { O contexto é favorável à ação. }\end{array}$ \\
$\begin{array}{l}\text { O contexto tem: } \\
\text { Todos os elementos "obrigatório ser verdadeiro", verdade; } \\
\text { Nenhum ou alguns elementos "desejáveis", verdade; } \\
\text { Todos ou alguns elementos "indesejáveis", verdade; } \\
\text { Todos os elementos "obrigatório ser falso", falsos. } \\
\text { O contexto é favorável à ação, mas deve ser verificado em termos de riscos potenciais } \\
\text { de elementos indesejáveis com potencial contribuição negativa. }\end{array}$ \\
$\begin{array}{l}\text { O contexto tem: } \\
\text { Pelo menos um elemento "obrigatório ser verdadeiro", falso; } \\
\text { Pelo menos um elemento "obrigatório ser falso", é verdade. } \\
\text { Os elementos "desejáveis" e "indesejáveis" tornaram-se irrelevantes. } \\
\text { O contexto é totalmente desfavorável à ação. }\end{array}$ \\
\hline
\end{tabular}

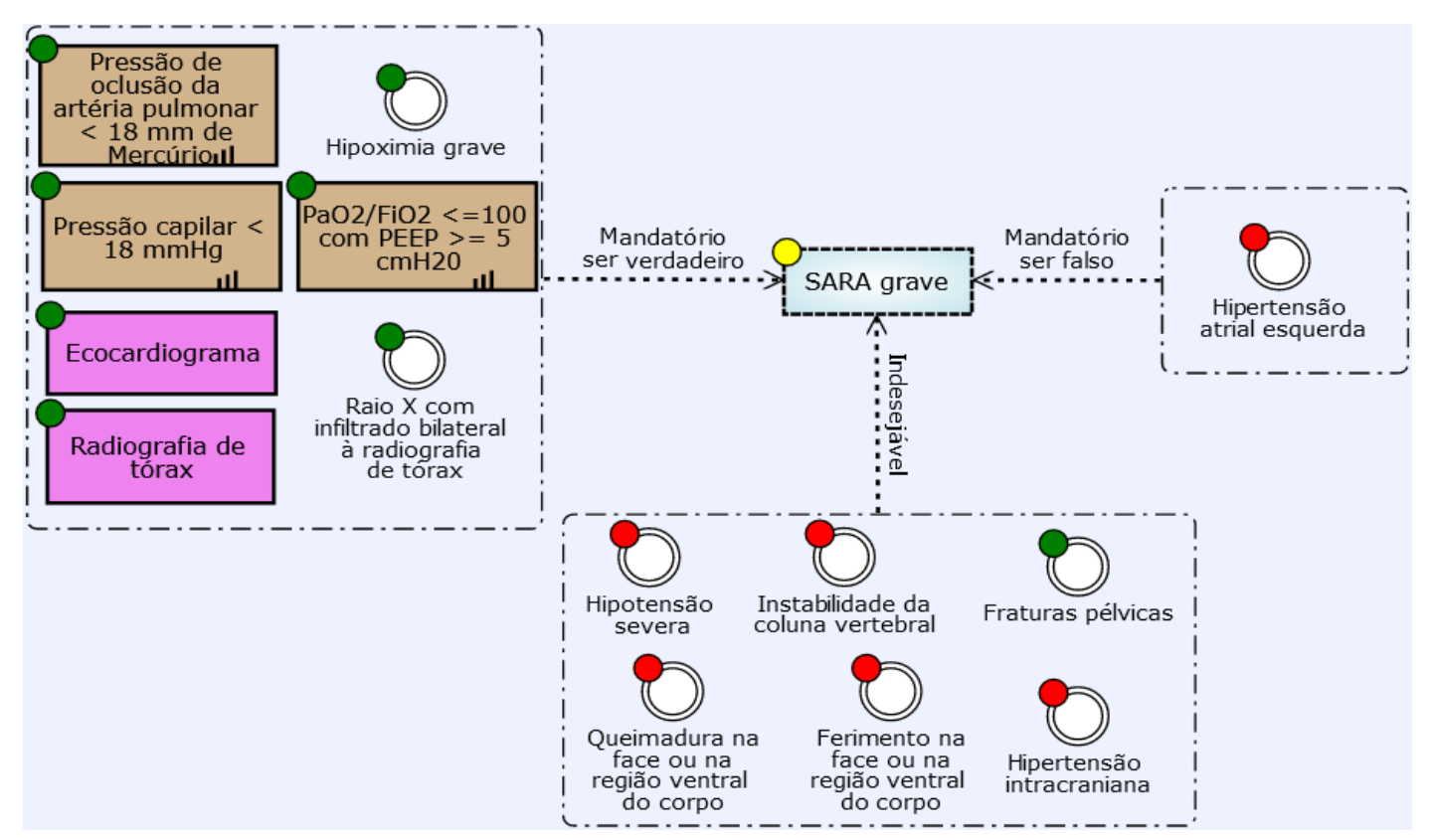

Figura 2.19. Situação de Contexto "SARA grave", com marcadores.

\subsubsection{Propagação de Marcadores ao Modelo Principal}

Os marcadores dos modelos de Perfil de Competência e Situação de Contexto são propagados para o modelo principal, onde está descrita a variabilidade de operacionalizações para o determinado objetivo (Figura 2.20).

As propagações de alinhamento de RH têm sua origem nos Perfis Reais, através da alocação de um Recurso Humano em um papel da organização. Esse marcador 
propaga para as tarefas e processos, prosseguindo para as respectivas competências e objetivos.

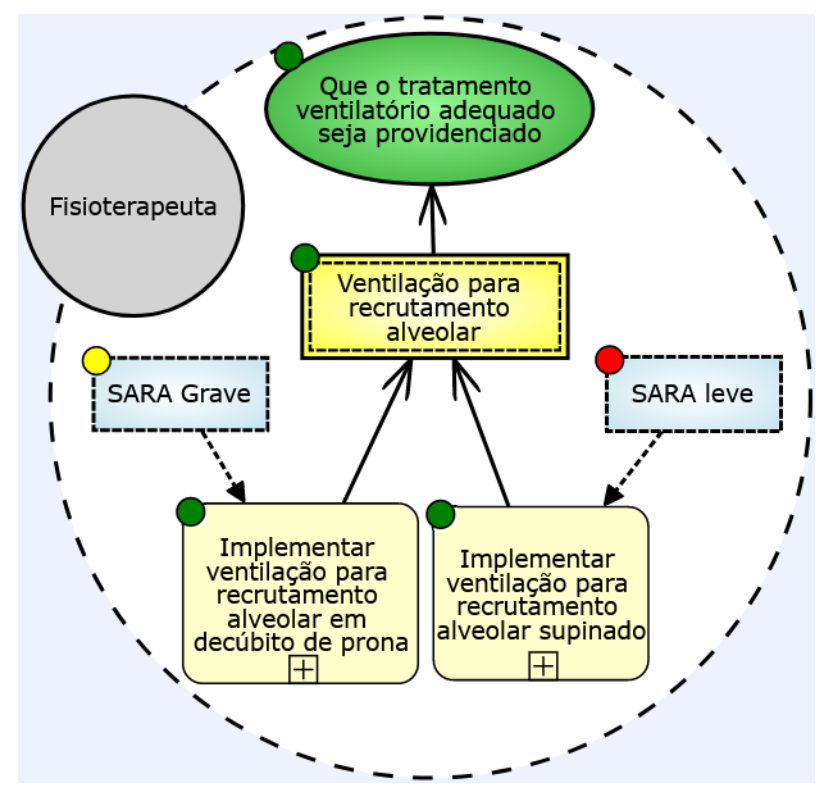

Figura 2.20. Propagação de marcadores até o objetivo.

Conforme já mencionado, o padrão de propagação do GPI-HR prioriza a propagação do marcador de menor valor. Essa estratégia de propagação auxilia a evidenciar problemas uma vez que eles sempre serão propagados em contrapartida aos marcadores superiores. Esta lógica de propagação também possibilita uma estratégia defensiva ao tomar decisões, já que sempre o pior caso será evidenciado. Nas análises de melhor caso, os marcadores de melhor posição devem ser desdobrados.

No exemplo da Figura 2.20, os processos estão com marcadores verdes, provenientes de um Perfil de Competências de um suposto RH. A marcação de Alinhamento de RH percorre o modelo propagando aos elementos superiores porque há nela uma conotação de impacto que pode ser positivo ou negativo.

Os marcadores da situação de contexto, assim como os marcadores de Alinhamento de RH, são elementos variáveis que servem como insumo para análises e decisões estratégicas. Os marcadores de situação de contexto não propagam, mas indicam se a operacionalização a qual ela está relacionada é plausível ou não de se implementar.

Neste caso, observa-se que a situação é de SARA grave, e que existem elementos relevantes a serem observados caso seja decidido implementar o processo "Implementar ventilação para recrutamento alveolar em decúbito de prona”. O elemento pode ser observado ao entrar no respectivo modelo de situação de contexto (Figura 2.19).

A variável de Alinhamento de $\mathrm{RH}$, neste caso, é neutra, porque ambas as operacionalizações possuem a mesma marcação verde. Entretanto, se houvesse distinção entre as marcações, o processo decisório deveria considerar este marcador, ainda que o contexto fosse favorável, uma vez que o risco de impactos de desalinhamento de $\mathrm{RH}$ pode ser grande.

Na avaliação e decisão estratégica, os pormenores podem ser decisivos. Toda informação presente pode ter um papel importante se ajudar a evitar possíveis problemas futuros. 


\subsection{Modelagem de um Exemplo}

Para consolidar o conteúdo apresentado até o momento, apresentamos uma descrição de caso, demarcada por tópicos, para facilitar o entendimento e a modelagem utilizando a linguagem GPI-HR.

O exemplo parte da perspectiva do ator Analista de empréstimos. Ele deve seguir uma estratégia definida para duas situações de mercado. O RH João é o indivíduo fictício definido neste exemplo. Seu perfil textual é apresentado para a interpretação do seu Perfil Real.

O exercício é seguido de uma proposta de modelagem para exemplificar o uso da linguagem. Seguem as descrições:

\subsubsection{Estratégia}

Descrição: João é Analista de empréstimo. Seu principal objetivo é que suas transações sejam lucrativas. Sua transação principal é o empréstimo. Para alcançar sua meta, João implementa uma estratégia de concessão agressiva de empréstimos quando o mercado está aquecido. Entretanto, quando o mercado está em recessão, João aplica regras específicas para dificultar o crédito a clientes que possuem maior risco de inadimplência.

Com essa descrição, foi possível modelar a Figura 2.21, contendo o objetivo, a competência que deve ser entregue e as duas possíveis formas de operacionalização, vinculadas a respectiva situação de contexto, definindo a sua estratégia em alto nível.

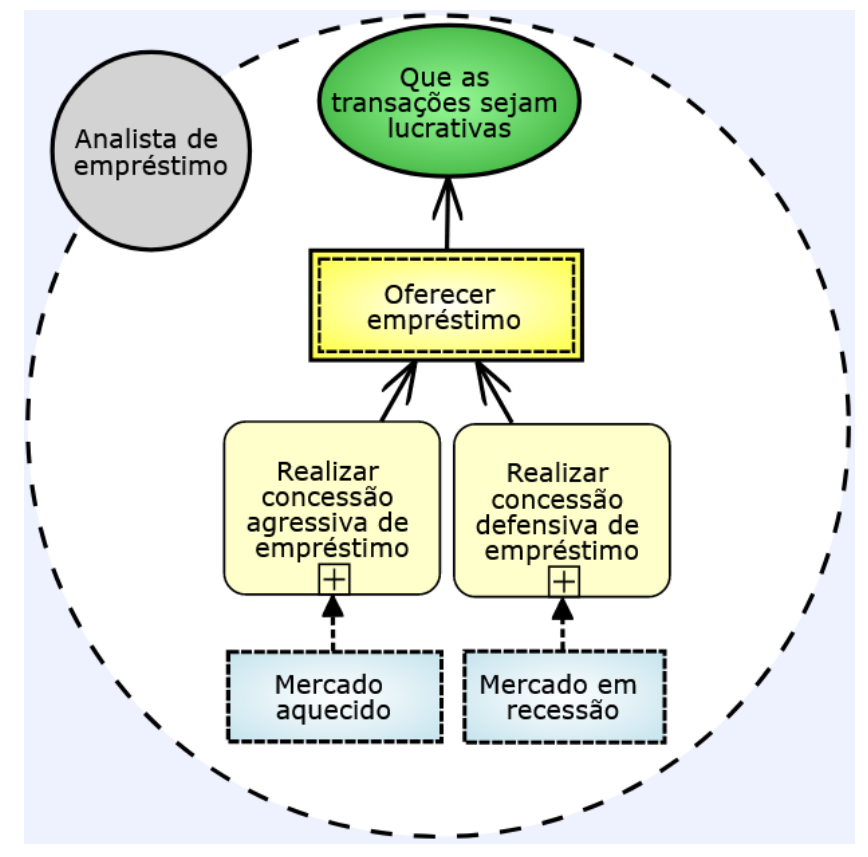

Figura 2.21. Modelo parcial apresentando as operacionalizações para "Oferecer empréstimo".

\subsubsection{Situação de contexto "Mercado aquecido"}

Descrição: O mercado está aquecido quando há baixa taxa de endividamento, baixa taxa de risco em empréstimos, baixa taxa de inadimplência no mercado, baixa taxa de juros e alta demanda por empréstimos. Também é necessário que a organização possua capital disponível para empréstimos e que não haja previsões de declínio no mercado. Às vezes existem políticas de subsídio governamental para empréstimos bancários, $o$ que é bem-vindo. Apesar do ambiente interno estar adequado, há de se observar as 
tendências internacionais, uma vez que não é interessante que este mercado esteja em crise, considerando a possibilidade de impacto nos mercados. Também é relevante observar se a concorrência está muito agressiva, obtendo a clientela através de promoções que vinculem muito risco às transações.

Atualmente os indicadores de taxa de endividamento, taxa de risco em empréstimos, taxa de inadimplência no mercado, taxa de juros estão altas, e a demanda por empréstimos está baixa. Externamente, há precisões de declínio do mercado, apoiado por um ambiente internacional em crise, o que é indesejado. Até o momento isso não afetou a nossa fatia de mercado em valor relativo, já que todas as empresas do ramo estão reduzindo sua carteira de clientes em valor absoluto. Isso não é diferente em nossa empresa, por isso precisamos observar. Infelizmente o governo cortou os subsídios provenientes do FGTS e da poupança, mas possuímos capital para empréstimos reservado.

Através da descrição foi definido o modelo de situação de contexto "Mercado aquecido”, conforme mostra a figura 2.22 .

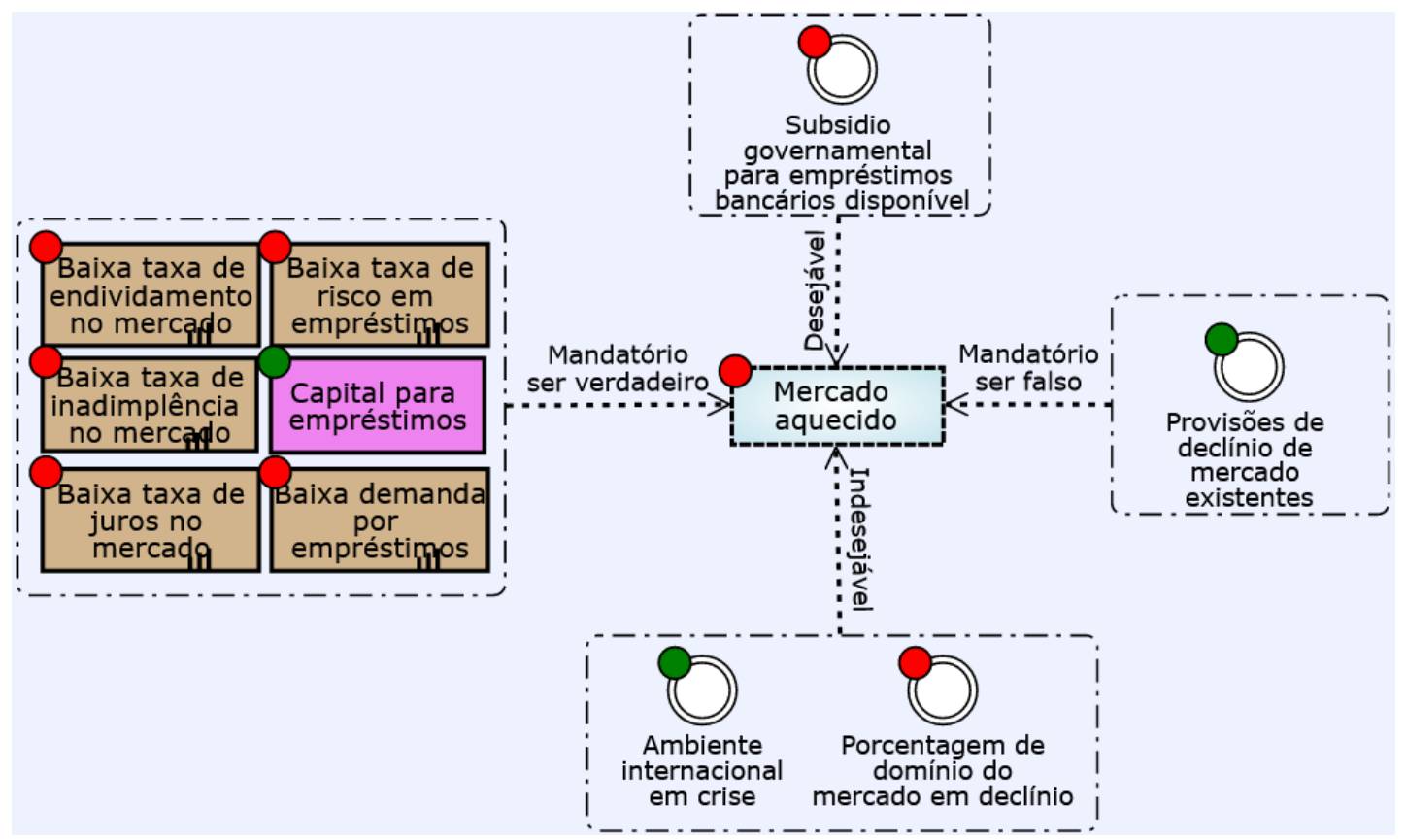

Figura 2.22. Situação de Contexto "Mercado Aquecido".

\subsubsection{Situação de Contexto "Mercado em Recessão"}

Descrição: O mercado está em recessão quando há alta taxa de endividamento, alta taxa de risco em empréstimos, alta taxa de inadimplência no mercado e alta taxa de juros. Para emprestar nesse cenário, a margem anual de perda de lucro seja menor que 5\%. Também é necessário que a organização possua capital disponível para empréstimos. Especificamente durante a recessão, é interessante se houver alta demanda a partir de clientes "especiais". Se houver competidores atuando de maneira agressiva, é importante observar os motivos. Eventualmente há alguma oportunidade no mercado que nossos analistas não identificaram. Não é interessante termos muitos clientes comuns pedindo empréstimo, porque todos serão negados, potencialmente causando insatisfação. Isso deverá ser observado de perto.

Nossos clientes "especiais" são a melhor opção para fechar contrato de empréstimos, já que o risco de calote é bem mais baixo do que entre os clientes comuns. Infelizmente, esta demanda não está alta. Mas até entre clientes comuns a demanda está baixa, e isso tem feito com que os competidores atuem agressivamente, se expondo 
ao risco. Trabalhamos para que a nossa perda de lucro seja menor do que 5\% quando há movimentos negativos no mercado, mas este ano esse valor já foi superado especialmente pela baixa procura por empréstimos em todas as classes sociais, motivada pela alta taxa de juros.

Através da descrição foi definido o modelo de situação de contexto "Mercado aquecido", conforme mostra a figura 2.23.

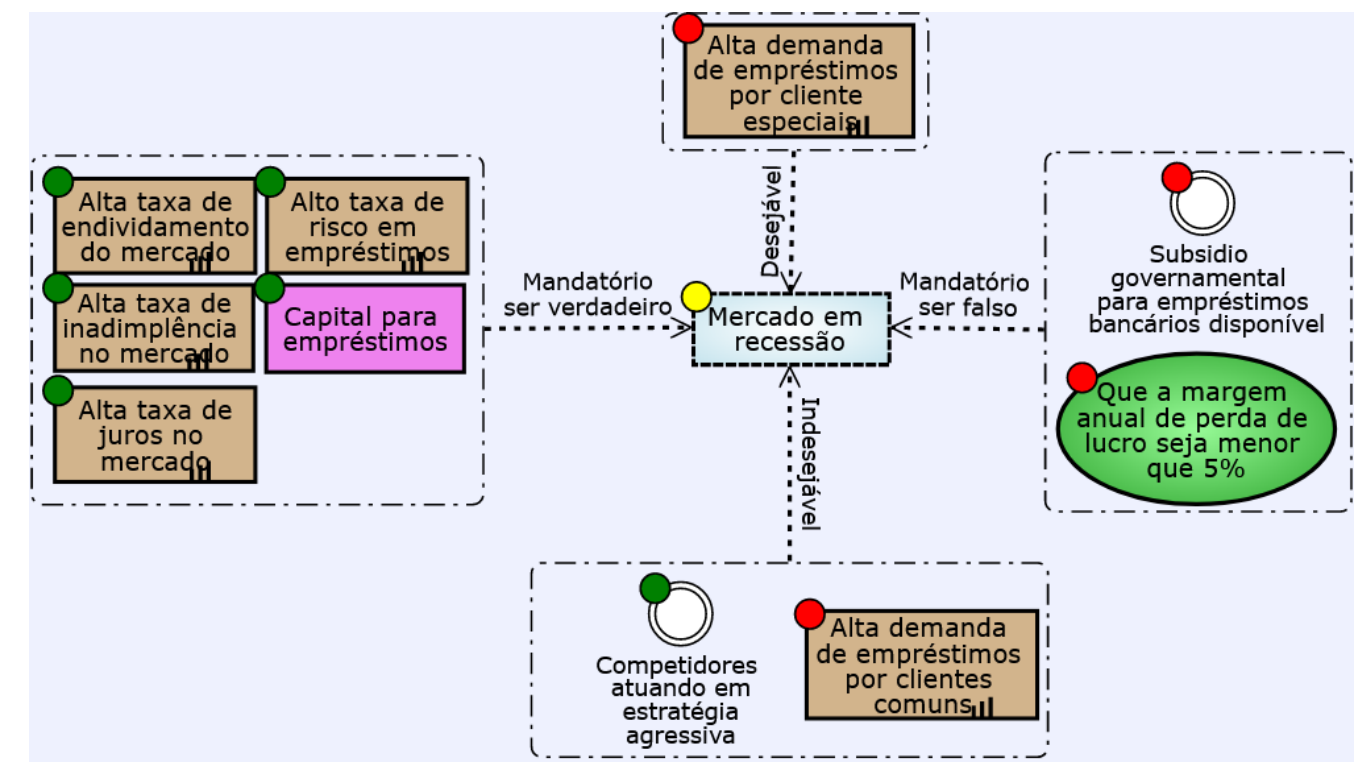

Figura 2.23. Situação de Contexto "Mercado em Recessão".

De acordo com a descrição, o mercado encontra-se em recessão. Isso é definido pelas variáveis mandatórias, as quais se enquadram nesta situação de contexto. Entretanto, há um ponto de atenção porque um elemento indesejável se faz presente. Os competidores estão atuando de forma agressiva em um ambiente de baixa. Isso pode ser uma medida necessária para que a empresa sobreviva em tempos difíceis, no entanto, essa decisão implica em riscos. Por isso, o marcador resultante da situação de contexto é amarelo. Esse marcador indica duas coisas: a primeira é que a situação de contexto é verdadeira; a segunda é que há elementos indesejáveis presentes no cenário, implicando na necessidade de se observar com cuidado qual é esse elemento e o motivo dele estar presente. Essas informações podem ser determinantes para uma melhor decisão estratégica. Nenhum elemento desejável está presente, mas, ainda que estivesse presente, o marcador permaneceria amarelo, visando expor os elementos indesejáveis presentes.

\subsubsection{Requisitos do Processo Concessão defensiva de empréstimo}

Descrição: Durante um período de recessão, quando João recebe uma demanda de empréstimo, ele segue o processo "Concessão defensiva de empréstimo". Neste processo são implementadas algumas regras específicas para a concessão de empréstimo, visando reduzir riscos inerentes de um cenário de mercado em recessão. A primeira regra é que o empréstimo seja concedido apenas para os clientes especiais, uma vez que o grau de risco de não pagamento destes clientes é bem menor do que as dos outros clientes. Além disso, vinculamos o empréstimo a garantia de algum bem penhorável. Os clientes especiais, no geral, possuem pelo menos um patrimônio penhorável, mas assim mesmo devemos verificar antes de conceder empréstimos se o bem ainda está disponível, se possui valor compatível para cobrir o valor de empréstimo solicitado, e se está livre e desembaraçado. Outra regra importante é 
garantir que o empréstimo aprovado seja depositado diretamente em uma conta nominal, para que possamos ter o comprovante de depósito. Alguns clientes informam contas de terceiros e pessoa jurídica, e o depósito nestas contas nos trouxe problemas no passado. Nestes períodos de recessão não temos produtos disponíveis para os clientes que não sejam especiais, então recusamos com os devidos cuidados e atenção ao pedido dos clientes comuns, visando mantê-los em nossa carteira de clientes.

A partir da descrição acima, foi definido o exemplo presente na Figura 2.24, estendendo a Figura 2.21.

Tabela 2.7. Elementos incluídos no modelo estratégico.

\begin{tabular}{|c|c|}
\hline ' Qualidade ' & $\begin{array}{l}\text { Representa uma qualidade que pode ser satisfeita em diferentes níveis, } \\
\text { dependendo da visão do avaliador. }\end{array}$ \\
\hline & $\begin{array}{l}\text { Representa um relacionamento de decomposição (semântica de “E” ou } \\
\text { “AND”). }\end{array}$ \\
\hline+ & $\begin{array}{l}\text { Representa um relacionamento de contribuição positiva. Especificamente } \\
\text { utilizado para relacionar operacionalizações a objetivos qualitativos. }\end{array}$ \\
\hline
\end{tabular}




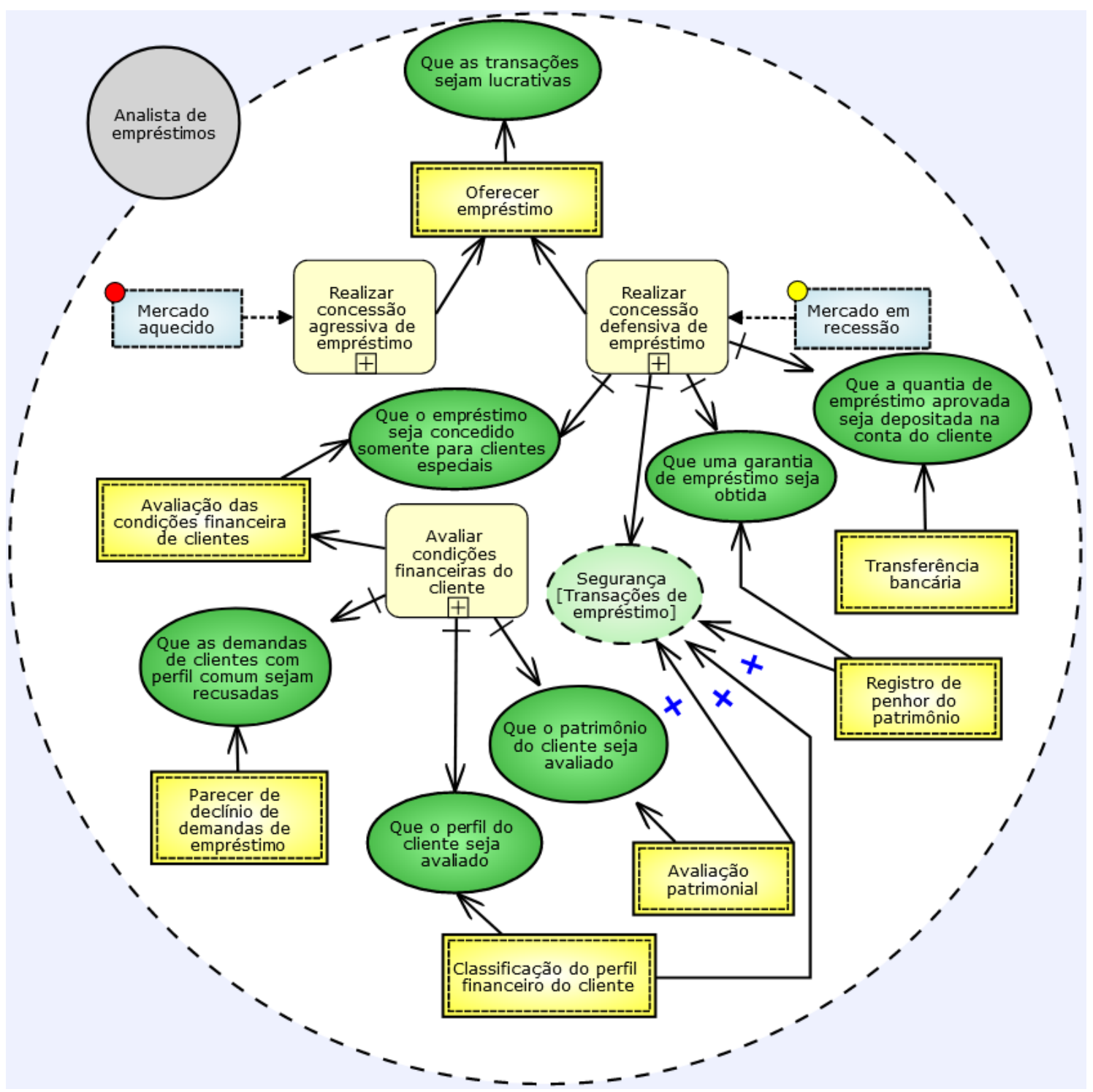

Figura 2.24. Modelo apresentando o detalhamento da operacionalização "Realizar concessão defensiva de empréstimo".

O conjunto de regras existentes dentro do processo de realizar concessão defensiva de empréstimo são requisitos que devem ser considerados na projeção das tarefas do processo. Esses requisitos são registrados como objetivos que decompõem o processo "Realizar concessão defensiva de empréstimo", os quais devem ser satisfeitos ao longo da sua execução, à medida em que são entregues competências. $O$ mapeamento desses objetivos detalha o que deve ser alcançado no nível operacional. As competências que deverão ser entregues para satisfazer os objetivos foram projetadas e relacionadas a eles.

Durante a execução do processo, essas competências serão entregues, satisfazendo todos os objetivos mapeados. Portanto, as tarefas descritas ao longo do processo são referentes às operacionalizações destas competências.

O processo “Avaliar condições financeiras do cliente” é um subprocesso de "Realizar concessão defensiva de empréstimo”, compondo-o juntamente com outras tarefas. Este subprocesso foi decomposto para explicitar três objetivos que devem ser alcançados durante a avaliação das condições financeiras do cliente. Por sua vez, esses objetivos estão relacionados às competências que os operacionalizam. Neste nível, essas 
competências não permitem mais decomposição, devendo ser relacionadas diretamente às partes do processo que a operacionalizam (será apresentado mais a frente).

\subsubsection{Processo (operacionalização Concessão defensiva de empréstimo)}

Descrição: Após receber a requisição, seu primeiro passo é classificar o perfil do cliente. Se o cliente for do tipo "Especial", ele verifica a existência de patrimônio para penhor (uma forma de garantia do empréstimo). Se o cliente possuir patrimônio disponível, ele registra o patrimônio como garantia de empréstimo no cartório. Posteriormente, deposita o valor do empréstimo diretamente na conta do cliente. Se o cliente não for "especial" ou não possuir patrimônio para penhora, a demanda de empréstimo é declinada e um parecer de declínio de empréstimo é emitido ao cliente.

Partindo desta descrição, o processo apresentado na Figura 2.25 foi construído:

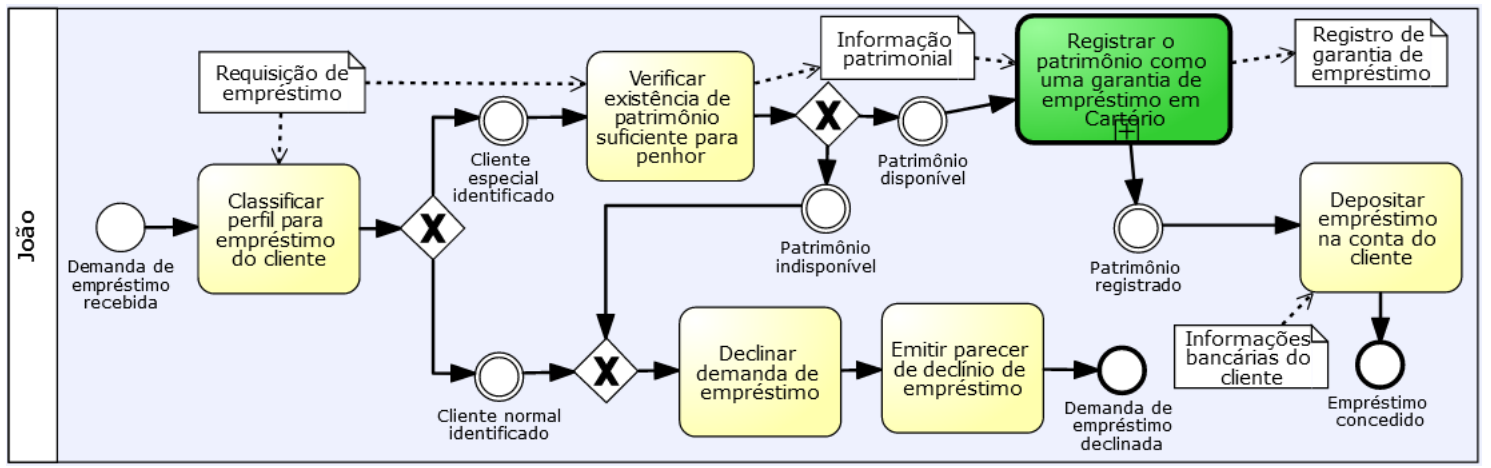

Figura 2.25. Modelo apresentando o detalhamento da operacionalização "Realizar concessão defensiva de empréstimo".

\subsubsection{Perfil de Competências para o ator Analisa de Empréstimos}

Descrição: Para atuar como analista de empréstimos, é necessário que o profissional tenha conhecimentos das regras internas de análise e classificação de perfis de cliente, bem como os valores patrimoniais do mercado atualizados. Não é fácil avaliar um patrimônio de forma adequada. O profissional deve ter um olhar minucioso e técnico. Nos processos internos, ele precisa saber trabalhar no computador, fazer consultas online, especialmente porque todos os nossos softwares são vinculados ao sistema bancário. É importante que o profissional consiga medir os riscos de um cliente em potencial para não termos problemas com inadimplência na carteira de empréstimos. Nós avaliamos o desempenho do profissional através de um indicador de inadimplência.

Especificamente nos processos em que existam registros patrimoniais no cartório, o profissional necessitará ser meticuloso e responsável, porque há prazos, os documentos devem estar impecáveis e, em caso de problema, ele deve estar apto a resolvê-los da melhor forma possível. Em cartórios, problemas são comuns, mas para tudo há um jeito.

A partir desta descrição, foram modelados dois Perfis Requeridos, sendo um referente às tarefas gerais, e outro referente a tarefa especializada "Registar o patrimônio como uma garantia de empréstimo em cartório”, a qual foi modelada como uma tarefa especializada (verde) no processo descrito na Figura 2.25.

Em ambos os perfis todos os elementos CHA foram modelados como obrigatórios. No perfil da tarefa especializada (Figura 2.26), foram definidos dois indicadores relacionados com a aptidão de responsabilidade para avaliar o desempenho 
do profissional no trato com os procedimentos e documentos cartoriais, uma vez que se trata de variáveis importantes para o bom desempenho da tarefa.

No perfil das tarefas básicas (Figura 2.27), foi definido um indicador para medir o desempenho da inadimplência na carteira de clientes como uma forma de avaliar a aptidão de mensuração de risco.

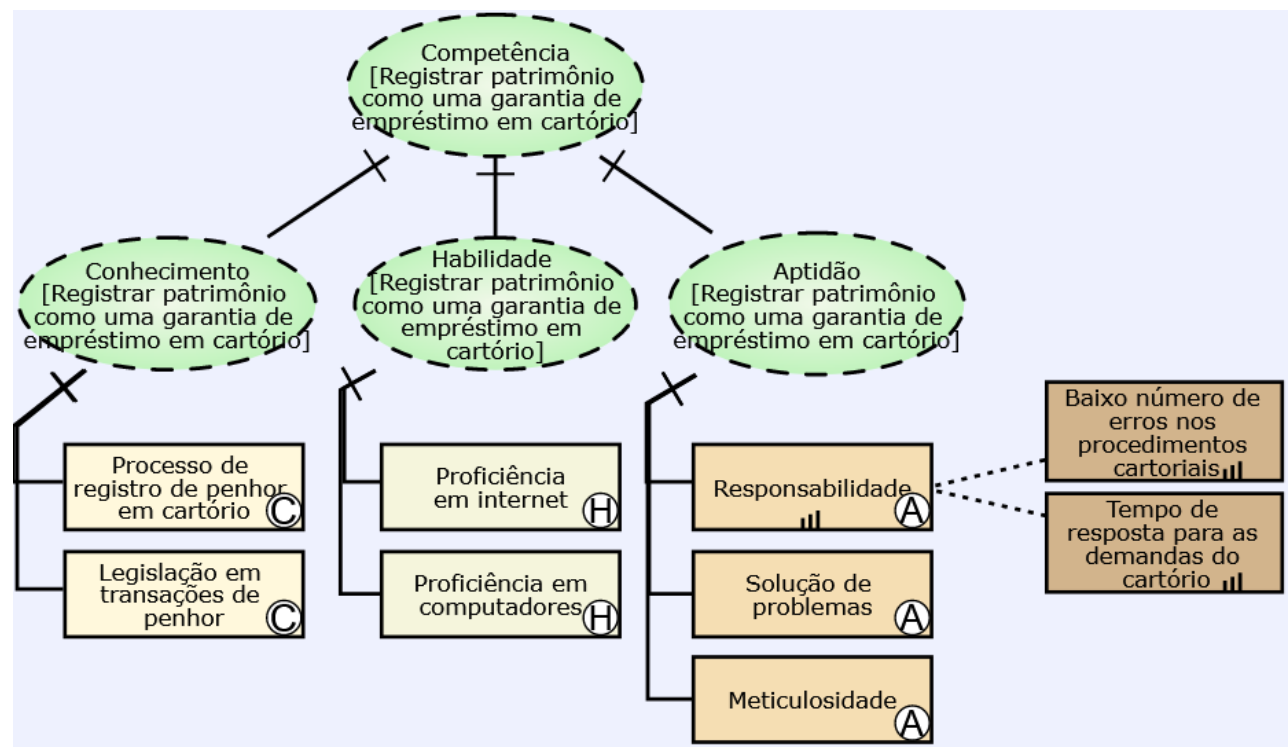

Figura 2.26. Perfil Requerido da tarefa "Registrar patrimônio como uma garantia de empréstimo em cartório".

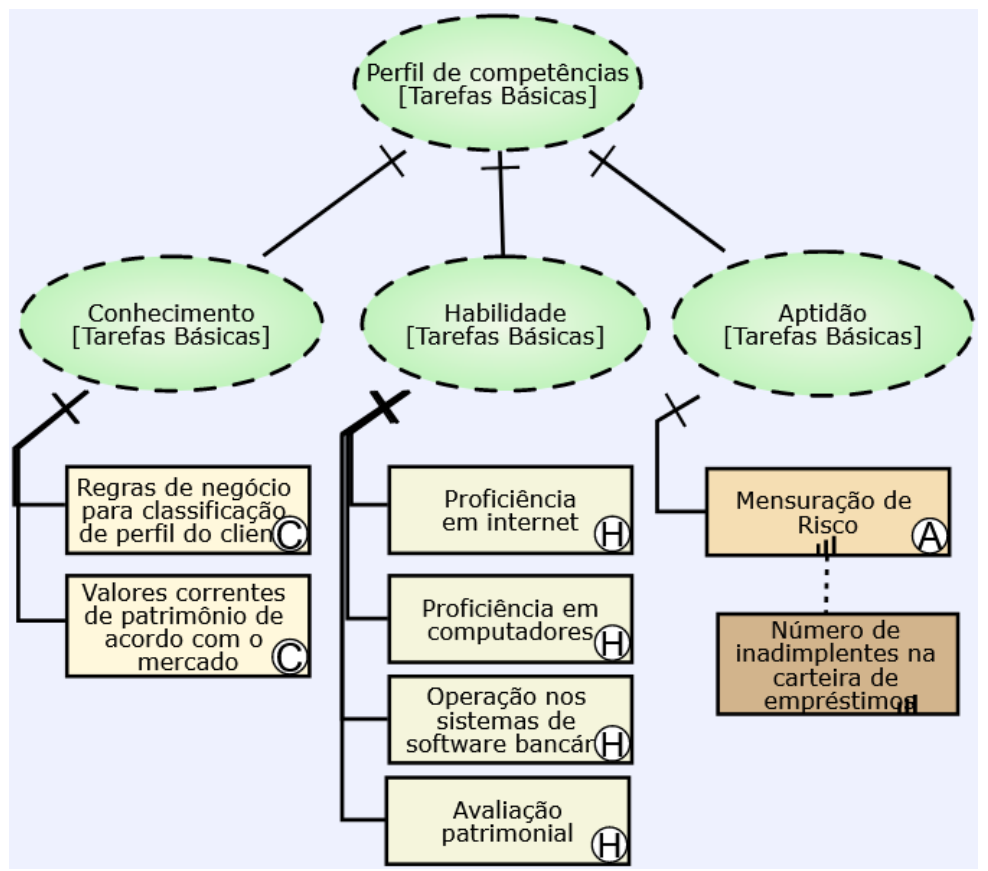

Figura 2.27. Perfil Requerido das tarefas básicas no processo "Realizar concessão defensiva de empréstimo".

\subsubsection{Perfil Profissional de João para Definição do Perfil Real}

Descrição: João é um excelente profissional, com grandes conhecimentos e habilidades. Não existem inadimplentes em sua carteira, e nos procedimentos cartoriais há baixo número de erros, entretanto, João anda um pouco relapso, perdendo prazos no cartório. Isso tem atrasado demasiadamente pedidos de empréstimo, fazendo com que o 
cliente desista. Além disso, perdemos dinheiro também para reabrir processos e refazer procedimentos.

Partindo da descrição do perfil profissional de João, foram construídos o Perfil Real das tarefas básicas (2.28) e o Perfil Real da atividade especializada (2.29). Em sua descrição, é possível observar que nos quesitos de conhecimentos e habilidades ele se encontra favorável, portanto, todas as marcações foram definidas como verde. $\mathrm{Na}$ aptidão de mensuração de risco, observa-se que João possui uma carteira impecável, sem nenhum registro de inadimplência, o que justifica o marcador azul em seu indicador de "Número de inadimplentes na carteira de empréstimo". Por consequência, esse marcador propaga para a aptidão "Mensuração de risco". O marcador final de Alinhamento de RH de João neste perfil é verde, demonstrando que ele possui competência para lidar com as tarefas básicas, apresentando o desempenho esperado no seu perfil de conhecimento e habilidades, e um desempenho superior no perfil de aptidão.

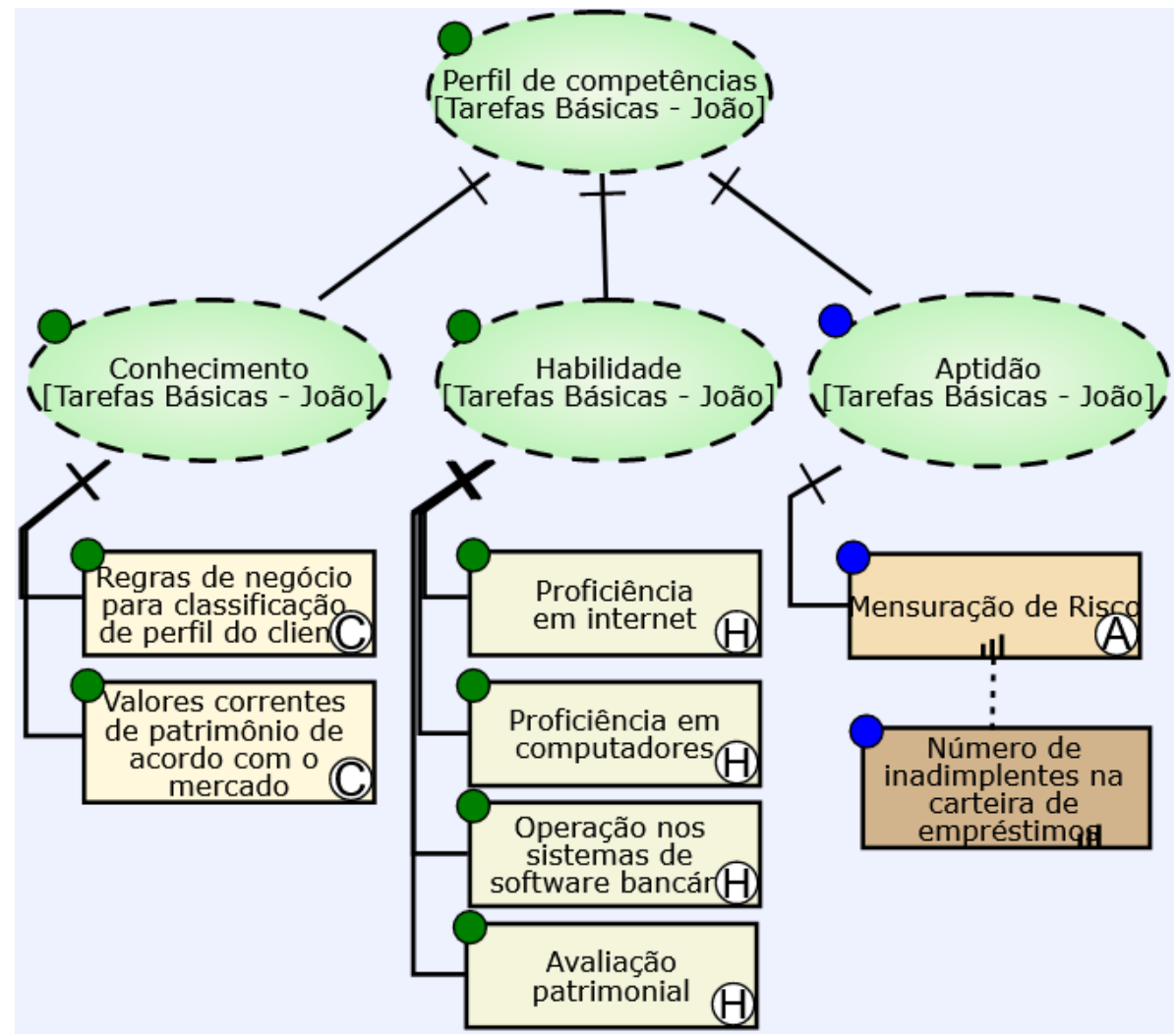

Figura 2.28. Perfil Real de João referente às tarefas básicas no processo "Realizar concessão defensiva de empréstimo".

No Perfil Real da tarefa especializada, o Perfil de conhecimento e habilidade seguiu as boas anotações, conforme no perfil anterior. Entretanto, na aptidão de responsabilidade há a descrição de problemas provenientes da perda de prazos no cartório. Por isso foi definido o indicador "Tempo de resposta para as demandas do cartório" como um indicador de responsabilidade. Por ser um relato de problema, utilizamos o marcador amarelo para este indicador, denotando o desempenho abaixo do esperado. $\mathrm{O}$ marcador poderia ser interpretado como vermelho, mas pela descrição, não parece se tratar da ausência grave do quesito de responsabilidade. Somente um problema isolado que possui potencial de ser contornado. 


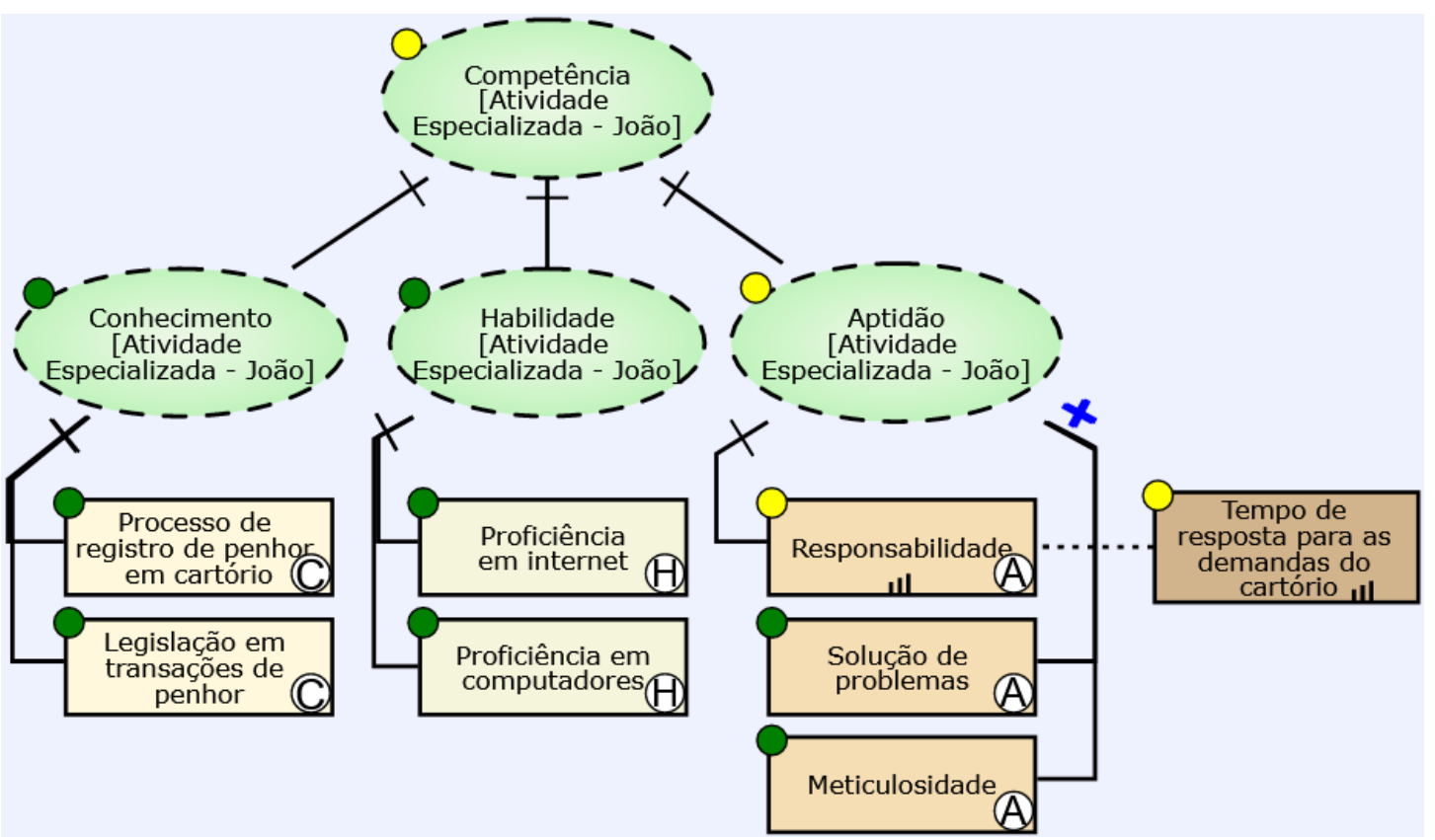

Figura 2.29. Perfil Real de João referente a atividade especializada no processo "Realizar concessão defensiva de empréstimo".

Ambos os perfis podem ser consolidados em um único perfil (Figura 2.30). Entretanto, separá-los auxiliará na identificação de seus impactos nos outros modelos. O marcador final de Alinhamento de RH para o João pode ser visto na Figura 2.30, que apresenta o exemplo de Perfil Real unificado.

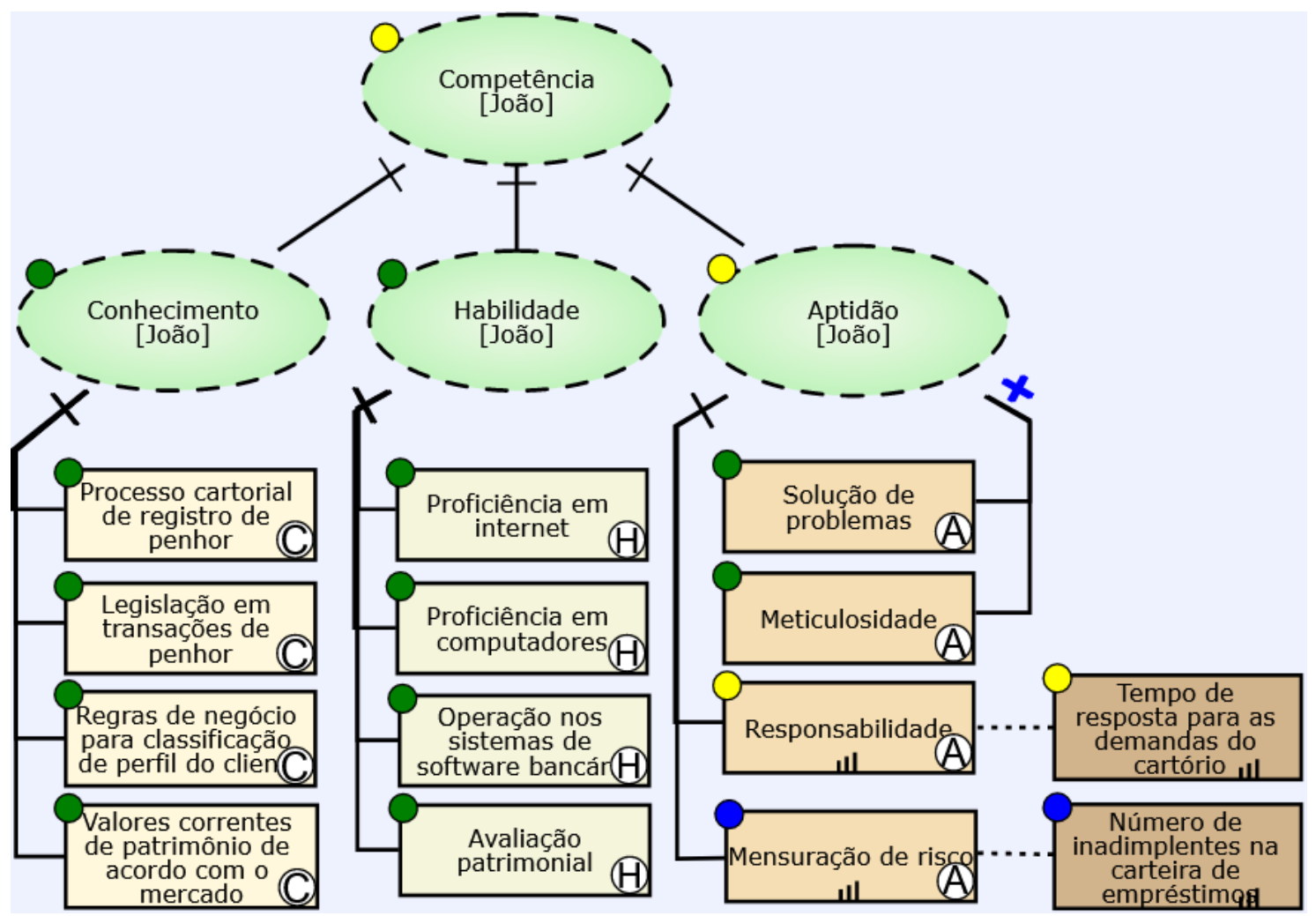

Figura 2.30. Perfil Real de João no papel de Analista de Empréstimos no processo "Realizar concessão defensiva de empréstimo".

\subsubsection{Alinhamento Entre Modelos e Propagação de Marcadores}


A tarefa de alinhamento entre modelos consiste na definição de relacionamentos entre o modelo estratégico (Figura 2.24) e o modelo operacional (Figura 2.25). Neste momento é possível identificar possíveis desalinhamentos presentes nos modelos, o que pode ser causado por fatores diversos como, por exemplo, ausência de informação, entendimento inadequado e desentendimentos de fontes de informação (quando há mais de uma).

O alinhamento entre modelos visa a relação entre tarefas do processo e respectivas competências. $\mathrm{O}$ alinhamento ocorre quando toda tarefa estiver vinculada a uma competência, e toda competência estiver vinculada a pelo menos uma tarefa. Desta forma não podem existir tarefas e competências sem relação, ou teremos tarefas sem justificativas de existir, ou competências sem operacionalização no processo. Caso ocorra um dos casos, é necessário identificar o motivo, obter as informações adequadas e corrigir o modelo.

Durante o mapeamento destes relacionamentos, há a possibilidade de críticas dos modelos, portanto esse procedimento também é uma oportunidade de verificar a corretude e completeza do modelo, além de possibilitar identificar problemas de entendimento e qualidade das informações pela perspectiva do modelador e de suas fontes de informação (stakeholders).

Após o mapeamento dos relacionamentos, será possível utilizá-los como pontes para a propagação dos marcadores presentes no modelo de processos para o modelo estratégico. Esses marcadores irão representar potenciais impactos por (des)alinhamento de $\mathrm{RH}$.

A Figura 2.31 apresenta o resultado do alinhamento e propagação dos marcadores. Utilizamos o recurso de "agrupamento" para relacionar duas tarefas a uma competência. A propagação seguiu a regra do pior caso, resultando um marcador amarelo no objetivo principal "Que as transações sejam lucrativas".

Este modelo final é o Diagrama Integrado do GPI-HR [Sousa e Leite, 2017]. A partir dele são feitas as considerações estratégicas, tendo como insumo, além do detalhamento da operacionalização no modelo estratégico e no modelo operacional, as informações de Alinhamento de RH, Situação de Contexto, e as opções de operacionalização para a entrega da competência que satisfaz o objetivo principal. 


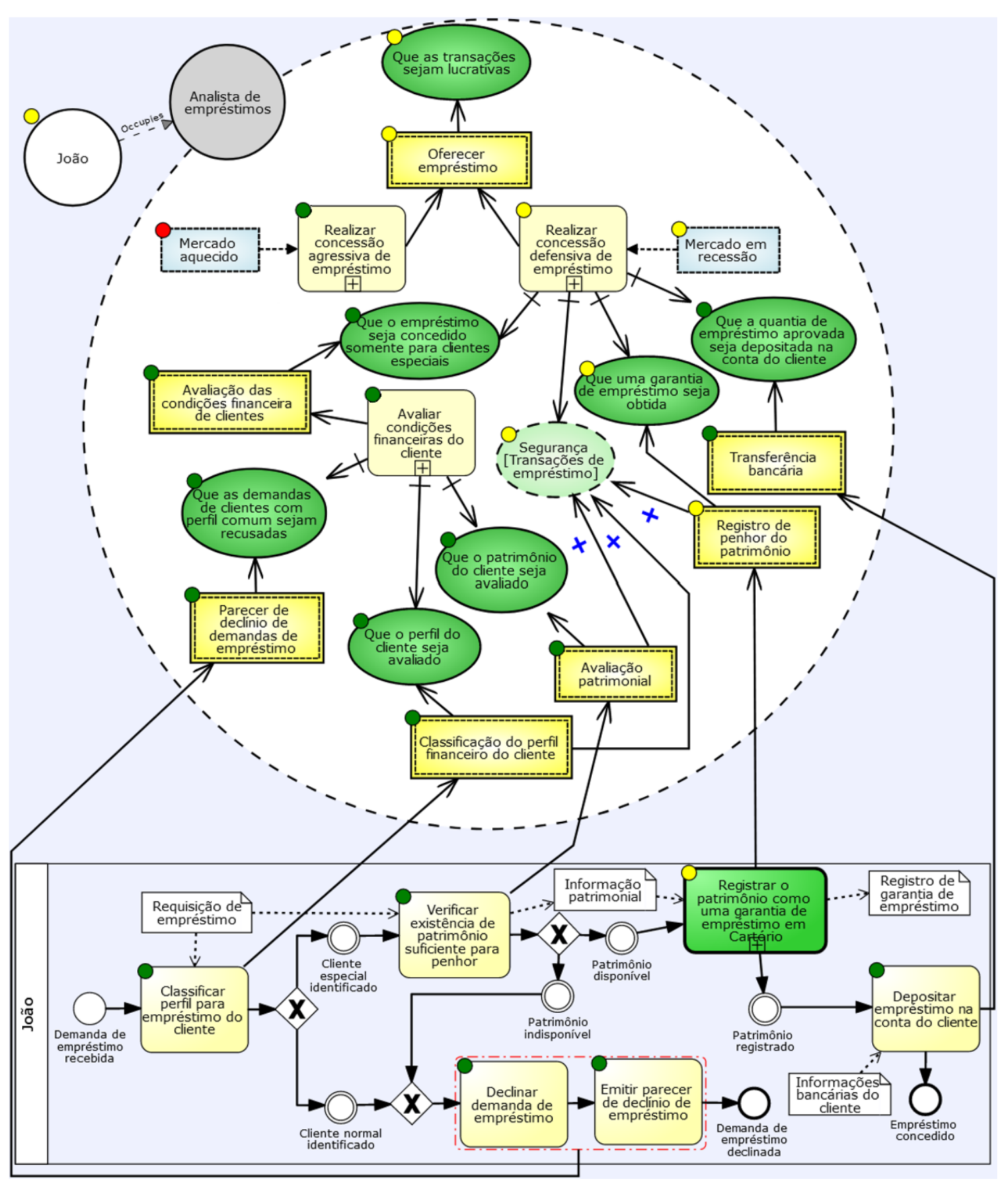

Figura 2.31. Diagrama Integrado.

\subsubsection{Análise do Alinhamento de RH e Estratégia}

A análise do alinhamento apresentada aqui é um exemplo. É possível obter diferentes interpretações e conclusões a partir do mesmo modelo.

O caso utilizado como exemplo demonstra um cenário de em que o mercado está em recessão. A indicação neste caso é a aplicação da operacionalização "Realizar concessão defensiva de empréstimo". Adicionalmente, temos um marcador amarelo nesta operacionalização, e na situação de contexto. Portanto, há a necessidade de se avaliar as causas.

Ademais, observa-se que a operacionalização "Realizar concessão agressiva de empréstimo" está com o marcado de alinhamento de RH verde, demonstrando maior probabilidade de sucesso na implementar desta operacionalização do que na outra. Isso 
também pode ser relevante na decisão estratégica, ainda que a situação de contexto indique que não está em mercado aquecido.

Observando através do modelo de situação de contexto, identifica-se que o há um elemento de contexto indicando que os competidores estão utilizando uma estratégia agressiva para obter clientes. Isso é indesejável em uma situação de mercado em recessão, pois neste momento a organização atua estrategicamente de forma defensiva, e o tom agressivo dos competidores pode piorar o enfrentamento da crise. Por outro lado, há de se verificar o motivo desse comportamento porque, talvez, os competidores possam ter observado algo relevante no mercado para atuar desta forma, o que é de interesse desta organização.

Quanto ao marcador de Alinhamento de RH, observa-se que há um desalinhamento pontual, por falta de desempenho em um indicador de responsabilidade. No entanto, isso pode afetar a concessão de empréstimo, porque faz referência a uma tarefa fundamental na concessão defensiva de empréstimo, e está relacionado à segurança nas transações e garantia do capital emprestado pela organização. A área de RH deve atuar neste desalinhamento, entretanto, há muitas possibilidades de intervenção. Por exemplo, atuar diretamente com o indivíduo para identificar o que pode estar motivando esse marcador.

É possível verificar que o perfil do indivíduo é bom, e há o desvio pontual no tempo de resposta para as demandas de cartório. Portanto, podemos entender que vale à pena investir no indivíduo João. Eventualmente seu problema é pessoal, e isso não é algo que se tornará explicito no dia a dia. A área de RH pode acompanhar problemas pessoais para apoiar o retorno deste recurso humano ao seu melhor desempenho. Para saber se essa seria uma boa solução, uma forma seria observar o histórico do recurso humano. Ele apresenta o problema de responsabilidade neste momento ou sempre apresentou? Essa informação não temos no modelo.

Outra ação é a chamada formal da melhoria deste aspecto, de forma transparente e profissional, fazendo com que o funcionário se conscientize do seu papel e impacto de eventuais erros para a organização.

Outras ações são possíveis, como a demissão ou substituição do recurso humano. Entretanto, entendemos que um problema pontual pode ser resolvido com menos atrito.

Por outro lado, a implementação da estratégia agressiva também pode ser uma opção, uma vez que o João apresenta marcador verde nesta operacionalização, e a concorrência, por algum motivo, está aplicando esta estratégia. Se essa motivação for plausível para a organização, essa pode ser uma decisão satisfatória, desviando dos problemas gerados na concessão defensiva de empréstimo (pelo menos por enquanto), e se alinhando à concorrência. Como há uma baixa procura por empréstimos, de forma geral, talvez essa seja a motivação dos competidores para atuar agressivamente.

Para que a organização não perca negócios em um momento difícil, talvez seja necessário atuar agressivamente, mesmo em um cenário de recessão e alto risco. A organização possui capital disponível, o que é um dos aspectos mais importantes nos tempos de crise.

Portanto, indicamos a possibilidade de se atuar de forma agressiva, considerando o marcador de Alinhamento de RH, para desviar do possível impacto negativo na estratégia defensiva, ao menos de uma forma imediata, enquanto trata do alinhamento 
do João. E a partir da interpretação das variáveis presentes nos modelos de situação de contexto, que mostram um cenário de baixa procura por empréstimos aliado às ações dos competidores em atuar de forma agressiva, ou seja, utilizando recursos para facilitar o acesso ao empréstimo visando obter clientes, ainda que existam riscos maiores envolvidos. exemplo.

Baseado neste modelo, estas são as considerações que apresentamos como

\subsection{Conclusão}

Este minicurso apresentou a Modelagem da Estratégia e Alinhamento de Recursos Humanos Baseado em Competências utilizando a linguagem GPI-HR. Foram utilizados casos simplificados para auxiliar no entendimento dos conceitos e uso da linguagem. A aplicação da linguagem em cenários reais pode demandar a atuação de profissionais de diversas áreas.

Para a construção de um modelo mais complexo, observamos que a linguagem envolve aspectos de diversas áreas, como a modelagem de processos e objetivos, a modelagem de perfis de competência, e a projeção e modelagem de estratégias. Esses modelos também podem envolver diversas áreas, sendo necessário elicitar informações a partir de diferentes grupos.

O trabalho de construção de um modelo amplo demanda minuciosa fase de elicitação para se obter informações suficientes para a construção adequada dos modelos. A qualidade dos modelos poderá influenciar nas interpretações que ele auxiliará a obter.

Portanto, a complexidade do modelo está diretamente associada à complexidade do domínio organizacional. Vinculada a análise estratégica, toda informação pode ser útil. Observamos que o Alinhamento de RH é apenas um aspecto na composição organizacional e que outras variáveis são muito importantes para a análise estratégica, como informações provenientes de outras áreas, por exemplo, de Finanças, Produção, Fornecimento, Marketing, Tecnologia da Informação, Jurídico, Comercial e Fiscal (não limitada a estes exemplos).

A linguagem GPI-HR se encontra em constante evolução, visando incluir de forma incremental, mais conceitos organizacionais pertinentes à análise estratégica e de alinhamento organizacional.

Estudos orientados a linguagens de domínios específicos são atualmente pesquisados visando extrair conhecimentos importantes para a definição de linguagens que apoiem a modelagem, facilite o entendimento e possibilite a análise através de modelos. 


\section{Referências}

AZEVEDO, C. L.; IACOB, M. E.; ALMEIDA, J. P. A.; VAN SINDEREN, M.; PIRES, L. F.; GUIZZARDI, G.; "Modeling resources and capabilities in enterprise architecture: a well-founded ontology-based proposal for ArchiMate"; Information Systems, 54, 235-262, 2015.

BARNEY, JAY B. Integrating organizational behavior and strategy formulation research: A resource-based analysis. 1992.

KLINK, Marcel van der; BOON, Jo. The investigation of competencies within professional domains. Human resource development international, v. 5, n. 4, p. 411424, 2002.

BRANDÃO, H.; PENA; G.; TOMÁS, DE A.; "Gestão de competências e gestão de desempenho: tecnologias distintas ou instrumentos de um mesmo constructo?"; Revista de Administração de Empresas, São Paulo, v.41, n.1, p.08-15, jan/mar, 2001.

CARBONE, P.; BRANDÃO, H.P.; LEITE, J.B.D., VILHENA, R.M.P.; "Gestão por competências e gestão do conhecimento"; Rio de Janeiro: Ed. Fundação Getúlio Vargas, 2005.

CURTIS. B.; HEFLEY, B.; MILLER, S.; "People Capability Maturity Model"; Software Engineering Institute; 2009.

DRAGANIDIS, F.; MENTZAS, G.; "Competency based management: a review of systems and approaches"; Information management \& computer security, 14(1), 5164, 2006.

DUTRA, Joel Souza . A gestão de pessoas articulada por Competências. Revista T\&D Inteligência Corporativa , v. 15, p. 20-21, 2007.

FLEURY, Maria Tereza Leme; FLEURY, Afonso. Em busca da competência. Encontro de Estudos Organizacionais, v. 1, 2000.

FLEURY, Maria Tereza Leme; FLEURY, Afonso. Construindo o conceito de competência. Revista de administração contemporânea, v. 5, p. 183-196, 2001.

FLEURY; M. T. L.; FLEURY; A. C. C.; “Alinhando estratégia e competências”; RAERevista de Administração de Empresas, vol. 44, n. 1, 2004.

FLEURY, Afonso; FLEURY, Maria Tereza Leme. Brazilian multinationals: competences for internationalization. Cambridge University Press, 2011.

GRANT, R. M.; "Toward a knowledge-based theory of the firm"; Strategic management journal, 17(S2), 109-122, 1996.

LIASKOS, S., JIANG, L., LAPOUCHNIAN, A., WANG, Y., YU, Y., DO PRADO LEITE, J. C. S., \& MYLOPOULOS, J. (2007). Exploring the Dimensions of Variability: a Requirements Engineering Perspective. VaMoS, 7, 17-26.

LOUCOPOULOS, P.; STRATIGAKI, C.; DANESH, M. H.; BRAVOS, G.; ANAGNOSTOPOULOS, D.; DIMITRAKOPOULOS, G.; "Enterprise capability modeling: concepts, method, and application"; In Enterprise Systems (ES), International Conference on (pp. 66-77). IEEE, 2015. 
MAIA, L. G.; MORAES, M. M.; FREITAS, L. C. O.; "Elaboração e avaliação de modelo de gestão de pessoas orientado por competências"; Perspectivas em Gestão \& Conhecimento, João Pessoa, v. 1, n. 1, p. 180-193, 2011.

MCKEOWN, Max. The strategy book. Pearson UK, 2019.

OMG; "Business Process Model and Notation (BPMN)"; Version 2.0, 2011.

PENROSE, E.; “The Theory of Growth of the Firm"; London: Basil Blackwell, 1959.

PICKTON, D. W.; WRIGHT, S. What's swot in strategic analysis?. Strategic change, 1998, 7.2: 101-109.

PORTER M. E. Competitive strategy. New York: Free Press, 1980.

PRAHALAD, C.K., HAMEL, G. The core competence of the corporation, Harvard Business Review (v. 68, no. 3) pp. 79-91, 1990.

SAXENA, K.B.; "Capabilities versus Competence: How are they Different?"; disponível em : https://www.linkedin.com/pulse/20141123155439-7430899capabilities-versus-competence-how-are-they-different.

SOUSA, H.P.S.; LEITE, J.C.S.P. Modeling Organizational Alignment. Lecture Notes in Computer Science. 1ed.: Springer International Publishing, 2014, v. 8824, p. 407414.

SOUSA, H.P., LEITE, J.C.S.P. Implementing GPI, a language for Organizational Alignment, Conceptual Modeling, Proceedings of the Eighth International $i^{*}$ Workshop (istar 2015), CEUR Vol-978, 2015.

SOUSA, H.P.S.; LEITE, J.C.S.P. Toward an Organizational Alignment Modeling Language: The Human Resource Competency Perspective. In: 2017 IEEE 19th Conference on Business Informatics (CBI), 2017, Thessaloniki. 2017 IEEE 19th Conference on Business Informatics (CBI), 2017a. p. 277.

SOUSA, H.P.S.; LEITE, J.C.S.P. Requirement Patterns for Organizational Modeling. In: 2017 IEEE 25th International Requirements Engineering Conference Workshops (REW), 2017, Lisbon. 2017 IEEE 25th International Requirements Engineering Conference Workshops (REW), 2017b. p. 252-259.

SOUSA, H. P. S.; ALMENTERO, E. K.; LEITE, J. C. S. P.. Relacionando requisitos de software e competências de recursos humanos através de modelos organizacionais. In: Workshop on Requirements Engineering, 2019, Recife. Anais do WER19 Workshop em Engenharia de Requisitos, 2019.

STEVENS, M.J.; CAMPION, M.A.; "The knowledge, skill, and ability requirements for teamwork: Implications for human resource management"; Journal of management 20.2 (1994): 503-530.

STIRNA, J.; GRABIS, J.; HENKEL, M.; ZDRAVKOVIC, J.; "Capability Driven Development - An Approach to Support Evolving Organizations"; In: Sandkuhl K., Seigerroth U., Stirna J. (eds) The Practice of Enterprise Modeling. PoEM 2012. Springer, Berlin, Heidelberg, 2012.

STRATEGYZER, A. G. "Het Business Model Canvas." (2015).

TRICHET, Francky; LECLÈRE, Michel. A framework for building competency-based systems dedicated to human resource management. In: International Symposium on 
Methodologies for Intelligent Systems. Springer, Berlin, Heidelberg, 2003. p. 633639.

VIGNOTTO, R.; "Como elaborar um (ótimo) dicionário de competências"; Portal Linked RH, $1^{\text {a }}$ edição, 2015.

\section{Autores}

Henrique Prado de Sá Sousa: é professor Adjunto do Departamento de Informática (DIA) da Universidade Federal do Estado do Rio de Janeiro (UNIRIO). Doutor em Engenharia de Software pela Pontifícia Universidade Católica do Rio de Janeiro (PUCRio). Mestre em Engenharia de Software pela Pontifícia Universidade Católica do Rio de Janeiro (PUC-Rio). Bacharel em Sistemas de Informação pela Universidade Federal do Estado do Rio de Janeiro (UNIRIO). Participou de diversos projetos de modelagem de processos de negócio e desenvolvimento de software, especialmente como engenheiro de requisitos. Ministra disciplinas da Engenharia de Software e Programação. Possui tese e dissertação no tema de construção de linguagens de modelagem para análise do alinhamento organizacional. Pesquisa continuamente a representação de conceitos específicos de domínio, orientado para a análise do alinhamento organizacional, bem como seu uso na engenharia de requisitos. Lattes: http://lattes.cnpq.br/5825446300218282.

Eduardo Kinder Almentero: É professor Adjunto do Departamento de Computação (DECOMP) da Universidade Federal Rural do Rio de Janeiro (UFRRJ). Doutor em Engenharia de Software pela Pontifícia Universidade Católica do Rio de Janeiro (PUCRio). Mestre em Engenharia de Software pela Pontifícia Universidade Católica do Rio de Janeiro (PUC-Rio). Bacharel em Ciência da Computação pela Universidade do Estado do Rio de Janeiro (UERJ). Tem experiência na área de Engenharia de Requisitos, atuando nas áreas de elicitação, modelagem e análise. Atualmente, ministra disciplinas de engenharia de software, gerência de projetos e gestão de TI. Realiza pesquisa sobre engenharia de requisitos, transparência de software e modelagem e alinhamento organizacional. Lattes: http://lattes.cnpq.br/8851661551732110. 